\title{
ZBTB7B (ThPOK) Is Required for Pathogenesis of Cerebral Malaria and Protection against Pulmonary Tuberculosis
}

\author{
James M. Kennedy, ${ }^{a, b}$ Anna Georges, ${ }^{a, b}$ Angelia V. Bassenden, ${ }^{a}$ Silvia M. Vidal,, ${ }^{b, c}$ (D) Albert M. Berghuis, ${ }^{a}$ Ichiro Taniuchi, ${ }^{d}$ \\ Jacek Majewski,c Mark Lathrop, c Marcel A. Behr, ${ }^{\text {,ff }}$ (D) David Langlais,, ${ }^{\text {b,c }}$ Philippe Gros ${ }^{a, b}$ \\ aDepartment of Biochemistry, McGill University, Montreal, Canada \\ bMcGill Research Center for Complex Traits, McGill University, Montreal, Canada \\ 'Department of Human Genetics, McGill University, Montreal, Canada \\ ¿Laboratory for Transcriptional Regulation, RIKEN Center for Integrative Medical Sciences, Yokohama, Kanagawa, Japan \\ eDepartment of Medicine, McGill University, Montreal, Canada \\ fInfectious Diseases and Immunity in Global Health Program, Research Institute of the McGill University Health Centre, Montreal, Canada
}

David Langlais and Philippe Gros contributed equally to this work.

ABSTRACT We used a genome-wide screen in $N$-ethyl- $N$-nitrosourea (ENU)-mutagenized mice to identify genes in which recessive loss-of-function mutations protect against pathological neuroinflammation. We identified an R367Q mutation in the ZBTB7B (ThPOK) protein in which homozygosity causes protection against experimental cerebral malaria (ECM) caused by infection with Plasmodium berghei ANKA. $Z b t b 7 b^{R 367 Q}$ homozygous mice show a defect in the lymphoid compartment expressed as severe reduction in the number of single-positive CD4 T cells in the thymus and in the periphery, reduced brain infiltration of proinflammatory leukocytes in $P$. berghei ANKA-infected mice, and reduced production of proinflammatory cytokines by primary $T$ cells ex vivo and in vivo. Dampening of proinflammatory immune responses in $Z b t b 7 b^{R 367 Q}$ mice is concomitant to increased susceptibility to infection with avirulent (Mycobacterium bovis BCG) and virulent (Mycobacterium tuberculosis H37Rv) mycobacteria. The R367Q mutation maps to the first DNA-binding zinc finger domain of ThPOK and causes loss of base contact by R367 in the major groove of the DNA, which is predicted to impair DNA binding. Global immunoprecipitation of ThPOK-containing chromatin complexes coupled to DNA sequencing (ChIP-seq) identified transcriptional networks and candidate genes likely to play key roles in $\mathrm{CD}^{+}{ }^{+} \mathrm{CD}^{+} \mathrm{T}$ cell development and in the expression of lineage-specific functions of these cells. This study highlights ThPOK as a global regulator of immune function in which alterations may affect normal responses to infectious and inflammatory stimuli.

KEYWORDS cerebral malaria, T cells, genetics, host response, immunity, immunology, infectious disease, malaria

erebral malaria (CM) is a rare and severe complication of Plasmodium falciparum infection in humans that manifests clinically with acute and rapidly fatal encephalitis (1). CM is characterized by high fever and rapidly progressing neurological symptoms (headaches, fever, delirium, seizure, and coma) that are lethal in $\sim 20 \%$ of affected individuals, with a preponderance in young children aged 3 to 5 years. Both vascular (microthrombosis, hypoxia, and vascular damage) and inflammatory (neuroinflammation) injuries drive pathogenesis in $\mathrm{CM}(2,3)$. Notably, upon sequestration of Plasmodium-parasitized erythrocytes in the brain microvasculature, activated endothelial cells release a number of potent inflammatory chemokines and cytokines (e.g., CXCL10) that attract myeloid and lymphoid cells to the site of infection. Infiltrating
Citation Kennedy JM, Georges A, Bassenden AV, Vidal SM, Berghuis AM, Taniuchi I, Majewski J, Lathrop M, Behr MA, Langlais D, Gros P. 2020. ZBTB7B (ThPOK) is required for pathogenesis of cerebral malaria and protection against pulmonary tuberculosis. Infect Immun 88: e00845-19. https://doi.org/10.1128/IAl.00845-19 Editor Andreas J. Bäumler, University of California, Davis

Copyright $\odot 2020$ American Society for Microbiology. All Rights Reserved. Address correspondence to Philippe Gros, philippe.gros@mcgill.ca.

Received 6 November 2019 Accepted 8 November 2019 Accepted manuscript posted online 2 December 2019

Published 22 January 2020 
leukocytes themselves secrete proinflammatory cytokines, such as gamma interferon (IFN- $\gamma$ ), tumor necrosis factor (TNF), and interleukin 1 (IL-1), that further weaken the integrity of the blood-brain barrier (BBB) and exacerbate cerebral pathology (4-7).

In mice, experimental cerebral malaria (ECM) can be induced by infection with Plasmodium berghei ANKA. Although the $P$. berghei ANKA mouse model does not reproduce all facets of human $C M$, there are several aspects of disease pathogenesis and host immune response that are common to both. The shared features include (i) rapidly progressing neurological symptoms, such as convulsions, paralysis, seizures, and coma; (ii) histopathology, including vascular obstruction, parenchymal hemorrhage, and weakening of the blood-brain barrier; (iii) sequestration of parasitized erythrocytes (pRBCs); (iv) overlapping host immune and inflammatory responses, including a key role of infiltrating monocytes, $\mathrm{T}$ cells, and platelets at the site of injury, astroglial activation, and upregulation of antigen presentation molecules (e.g., major histocompatibility complex class 1 [MHC-I] and MHC-II) and of host endothelial adhesion molecules (e.g., ICAM-1) on cerebral vessels (8-12).

In the ECM model, $\mathrm{CD}^{+}$and $\mathrm{CD}^{+}{ }^{+} \mathrm{T}$ cells play critical roles in driving neuroinflammation and associated lethal pathology. The maturation and differentiation of $\mathrm{CD}^{+}$ and $\mathrm{CD}^{+}{ }^{+} \mathrm{T}$ cells is a tightly regulated process that begins during intrathymic selection of double-positive $\mathrm{CD}^{+}{ }^{+} \mathrm{CD}^{+}$thymocytes to single-positive $\mathrm{CD}^{+}$and $\mathrm{CD}^{+}{ }^{+} \mathrm{T}$ lymphocytes (13). Differentiation is initiated by $T$ cell receptor (TCR) engagement by self-peptide $\mathrm{MHC}$ complexes on intrathymic endothelial cells, with $\mathrm{CD}^{+}{ }^{+} \mathrm{T}$ cells being $\mathrm{MHC}$ class II restricted while $\mathrm{CD} 8^{+} \mathrm{T}$ cells are $\mathrm{MHC}$ class I restricted. The differentiation of $\mathrm{CD}^{+}$and $\mathrm{CD}^{+} \mathrm{T}$ cells is orchestrated by a number of transcription factors, in particular SATB1, RUNX3, GATA3, and ZBTB7B (ThPOK) (14). During ECM, CD4 ${ }^{+}$and $\mathrm{CD}^{+} \mathrm{T}$ cells become activated in response to myeloid cytokines and other danger signals and migrate to the brain, where they drive immunopathology $(3,15)$. This is exemplified by the observation that single gene mutations that affect the numbers, maturation, or activation of $\mathrm{CD}^{+}{ }^{+}$and $\mathrm{CD} 8^{+} \mathrm{T}$ cells $(C d 4, C d 8, J a k 3$, Themis, Ccdc88b, Mapk9, and Lck) (16-21), including the production (Irf8, Irf1, Stat1, and Usp15) $(22,23)$ of proinflammatory cytokines (Ifng, Ifnar1, and I/2) and their receptors (Ifngr1 and I112rb2), as well as other T cell-specific cytotoxic molecules (Lta and Ltb), blunt neuroinflammation and protect mice against lethality in the ECM model $(6,8,24)$.

We used genome-wide mutagenesis with $N$-ethyl- $N$-nitrosourea (ENU) in vivo to identify genes and pathways that, when inactivated, protect against lethal neuroinflammation and cause ECM resistance in P. berghei ANKA-infected mice (25). Our breeding scheme was designed to detect recessive mutations where the protective effect in ECM is seen in homozygotes segregating at an expected ratio of $\sim 25 \%$ in third-generation offspring of an ENU mutant mouse pedigree. The mutations causing ECM resistance are identified by subsequent segregation analyses coupled with wholeexome sequencing, presenting as a de novo homozygous mutation in independent ECM-resistant mice from the same pedigree. The robustness of this screen was validated through the identification of mutations in genes (e.g., Jak3, Themis, and FoxN1) that are known to play a role in inflammatory and immune functions and allowed the identification of novel contributors to neuroinflammation ( $C c d c 88 b$ and Usp15) (19-21, 23).

In this study, we identified a pedigree (Farris) that harbors ECM-resistant animals. Exome sequencing in independent mice from this G1 (see Materials and Methods) male revealed the presence of a single arginine-to-glutamine missense mutation at position 367 of the protein ThPOK. ThPOK is a member of the $\mathrm{C}_{2} \mathrm{H}_{2}$ family of zinc finger domain (ZFD)-containing transcription factors, and three-dimensional (3D) structural modeling showed that the mutation maps to the DNA-binding domain of the protein in the first $\mathrm{Zn}$ finger at a residue that makes key base contacts in the major groove. On the other hand, $Z b t b 7 b^{R 367 Q}$ mutant mice show increased susceptibility to infection with avirulent (Mycobacterium bovis BCG) or virulent (Mycobacterium tuberculosis H37Rv) mycobacteria, with increased bacterial replication in target organs and reduced survival. ECM resistance and susceptibility to pulmonary tuberculosis (TB) is associated with de- 
A

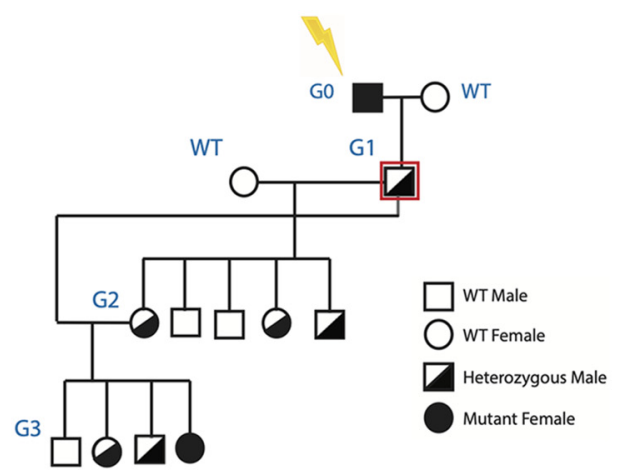

C

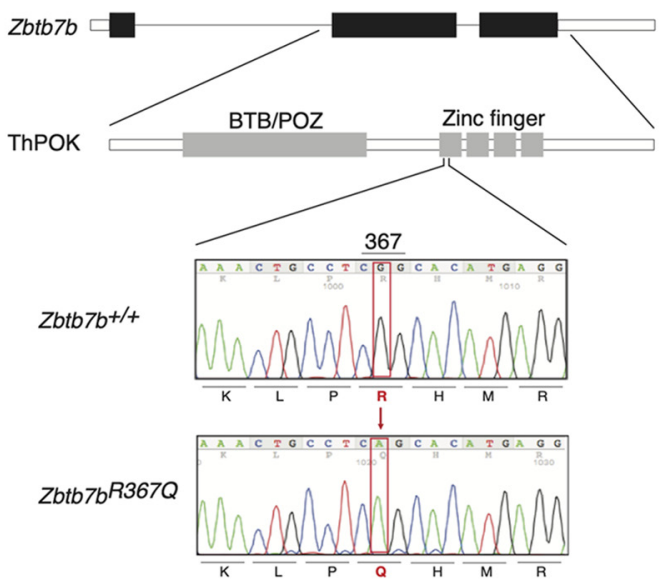

B

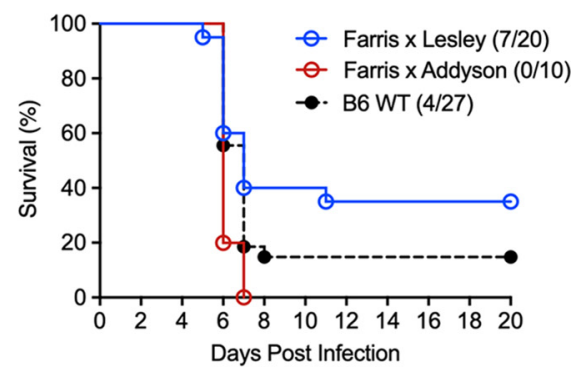

D

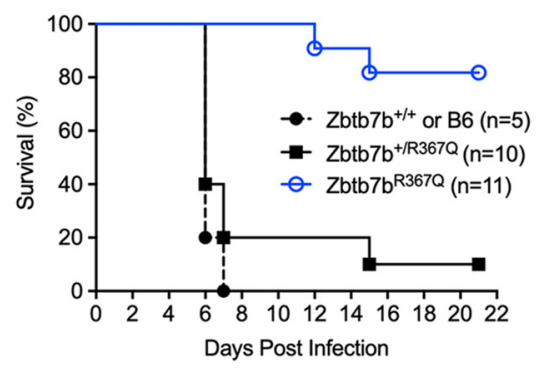

FIG 1 An ENU-induced mutation in Zbtb7b protects mice from ECM. (A) Breeding scheme for the production of ENU mutant mice. The G1 male (boxed in red) was independently bred to one or two G2 females to produce individual G3 pedigrees, which were infected with $P$. berghei ANKA and monitored for the appearance of phenodeviant ECM-resistant animals. (B) Survival of G3 mice from pedigree Farris obtained by breeding Farris to G2 females Lesley and Addyson. Mice were infected i.v. with $10^{6}$ P. berghei ANKA pRBCs and monitored for the appearance of neurological symptoms and clinical endpoints. Any mouse surviving past day 13 was considered ECM resistant. (C) Whole-exome sequencing of 3 ECMresistant mice from the $\mathrm{G} 3$ cross of Farris $\times$ Lesley revealed a G-to-A transition in exon 2 of $Z b t b 7 b$, resulting in an arginine (R)-to-glutamine (G) amino acid change at position 367 in the first zinc finger domain of ThPOK. (D) Survival of Zbtb7b homozygous mutant mice (Zbtb7bR367Q; $n=11$ ), heterozygous mice $\left(Z b t b 7 b^{+/ R 367 Q ;} n=10\right)$, and wild-type mice $\left(Z b t b 7 b^{+/+} ; n=5\right)$ after infection with $10^{6}$ P. berghei ANKA pRBCs.

creased numbers and activity of $\mathrm{CD}^{+} \mathrm{T}$ cells in the mutant. Studies by chromatin immunoprecipitation and DNA sequencing (ChIP-seq) showed that ThPOK is a critical regulator of gene expression in thymocytes, including expression of the lineage determination of the transcription factor gene Runx3.

\section{RESULTS}

A mutation in ZBTB7B (ThPOK) protects mice against neuroinflammation in cerebral malaria. We used genome-wide ENU mutagenesis in a phenotype-driven screen in vivo to identify stably segregating mutations that protect mice against lethal ECM induced by infection with $P$. berghei ANKA. These mutations are likely to identify genes that play an important role in pathological neuroinflammation. A recessive breeding scheme was implemented to generate small families of G3 animals from a second backcross in which a small number of ENU-induced mutations were expected to segregate (26). Groups of G3 mice were infected with $1 \times 10^{6} P$. berghei ANKA pRBCs and were monitored for the appearance of neurological symptoms of EMC and for survival (Fig. 1A). In C57BL/6J (B6) wild-type (WT) animals, neurological symptoms (paralysis, seizures, and tremors) begin at day 5 postinfection (p.i.), with susceptible mice succumbing to infection by day 9 postinfection. Any animal surviving past day 13 was flagged as resistant to $P$. berghei ANKA-induced ECM (ECM resistant). 
Crossing G1 male Farris to G2 female Lesley mice produced 7 of 20 G3 animals that were ECM resistant, corresponding to an overall survival rate of $35 \%$, suggesting segregation of a single autosomal recessive ECM-protective mutation in these animals (Fig. 1B). Exome sequencing of 3 resistant mice from the pedigree revealed a homozygous guanine-to-adenine transition in exon 2 of the gene Zbtb7b (chr3; 89,184,332 bp; genome build NCBI37/mm9). Zbtb7b encodes a transcription factor, and the mutation results in an arginine-to-glutamine amino acid change at position 367 in the first zinc finger of the DNA-binding domain of the protein (Fig. 1C). Breeding mice to homozygosity for the $Z b t b 7 b^{R 367 Q}$ mutation confirmed its protective effect (increased survival) compared to either heterozygotes (Zbtb7b+/R367Q) or WT $\left(\right.$ Zbtb $\left.7 b^{+/+}\right)$littermates (Fig. 1D).

R367Q mutation is predicted to affect DNA binding. ZBTB7B (ThPOK) (27) is a member of the well-characterized $\mathrm{C}_{2} \mathrm{H}_{2}$ family of zinc finger domain-containing transcription factors. It is comprised of four ZFDs involved in DNA binding, as well as a $\mathrm{BTB} / \mathrm{POZ}$ ( $\underline{B} R-\mathrm{C}, \underline{\mathrm{t} t \mathrm{k}}$, and $\underline{\mathrm{b}} \mathrm{ab} / \mathrm{pox}$ irus and zinc finger) domain that is responsible for homotypic dimerization upon DNA binding. To visualize the steric effects of the R-to-Q mutation at position 367, in the first $\mathrm{Zn}^{2+}$ finger domain (ZFD1) of ThPOK, we modeled the R367 and Q367 residues using the available structure of the DNA-bound $\mathrm{Zn}^{2+}$ finger domain of the protein Aart (28), which shares 39\% sequence identity to the corresponding domain of ThPOK. These studies show that (i) ZFD1 probably plays an important role in DNA binding, and its alpha helix structure is inserted tightly into the major groove of DNA; (ii) R367 is located at a key position of ZFD1 and makes base-specific contacts through 2 hydrogen bonds from the $\mathrm{NH}_{2}$ side chain of arginine 367, 2.6 and 3.4 $\AA$, respectively; (iii) these two hydrogen bonds are lost when the Q367 variant is modeled into the structure, strongly suggesting that the Q367 variant has reduced affinity for DNA, with reduced stability of the mutant Q367-DNA complex compared to wild-type R367 (Fig. 2A).

Mutations in the DNA-binding domains of certain transcription factors sometimes also result in protein misfolding, reduced stability, and/or increased degradation. Hence, a further possible effect of the R367Q mutation on protein stability was investigated by comparing the total amounts of ThPOK protein in the spleens and thymuses of WT mice and Zbtb7b $b^{R 367 Q}$ mutants, two tissues that are known to express the protein (29) (Fig. 2B). Immunoblotting studies identified a major 70-kDa immunoreactive species in the spleen and thymus, which corresponds to the predicted size of full-length ThPOK and that reported in the literature (29). This 70-kDa protein band is also absent in the spleens and thymuses of ThPOK knockout mice, in which the Zbtb7b coding sequence is replaced by the gene encoding green fluorescent protein (GFP) (ThPOKGFP/GFP), further confirming this 70-kDa band as ThPOK. As shown in Fig. 2B, we observed moderately increased expression of ThPOK protein in the thymus and spleen in Zbtb7b $b^{R 367 Q}$ mice compared to WT B6 mice, with a greater effect in the thymuses of Zbtb7b $b^{R 367 Q}$ mice.

ThPOK is bound to genes involved in ontogeny and activity of lymphoid cells. Given that ThPOK is a transcription factor expressed in thymocytes (29) and that the R367Q mutation is likely to affect DNA binding, we aimed to systematically identify the genes bound (cistrome) and possibly regulated by ThPOK and whose altered expression may underlie the altered inflammatory response phenotype of mutant mice. We prepared chromatin from Th1 polarized $\mathrm{CD}^{+}{ }^{+} \mathrm{T}$ cells, a cell type known to be a major driver of pathological neuroinflammation in the ECM model (8), and conducted ChIPseq. We found that ThPOK is recruited to 6,314 genomic sites and that $\sim 73 \%$ of those sites are within $5 \mathrm{~kb}$ of a gene transcriptional start site (Fig. 3A; see Table S1 in the supplemental material) in comparison to $7 \%$ for sets of randomly generated sites. The detected ThPOK binding was specific, significantly enriched over background, and enriched for guanine and cytosine (Fig. 3B and C). De novo binding motif analysis was performed on $200 \mathrm{bp}$ of DNA fragments at the identified binding peaks (Fig. 3C) to identify the ThPOK binding motif; this analysis revealed the motif (G/A)N(G/A)NCC(C) A)CN to be significantly enriched and centered at ThPOK binding peaks. This motif is 

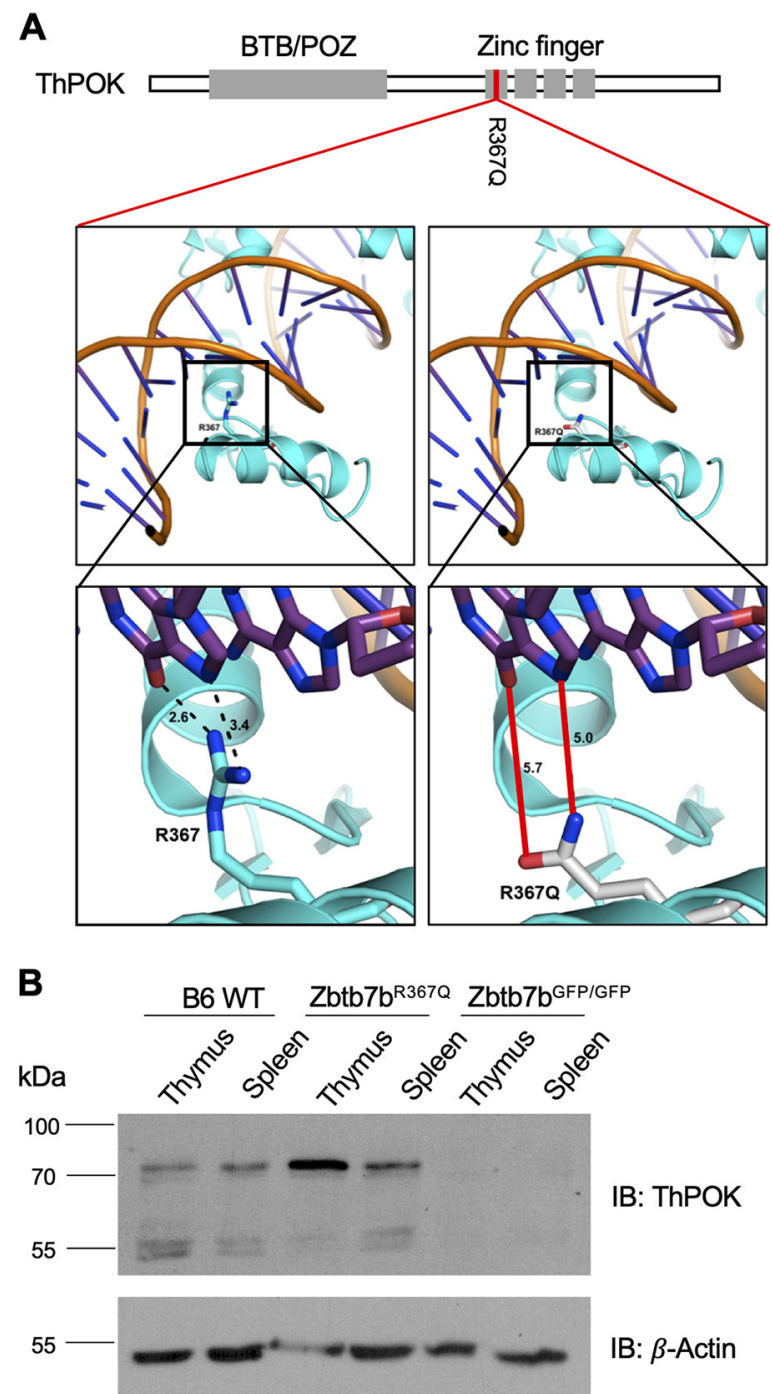

FIG 2 Molecular modeling of DNA-bound ThPOK. (A) Molecular modeling of wild-type R367 and mutant Q367 residues on the three-dimensional structure of DNA-bound ThPOK; coordinates are from the Aart protein relative. The bottom images are magnifications of the boxed areas in the top images. The positions of critical hydrogen bonds (dashed lines) between R367 and DNA bases in the major groove are indicated with their predicted lengths, showing significant disruption (solid red lines) in the Q367 mutant. (B) Total protein lysates were prepared from thymuses and spleens of wild-type (B6), Zbtb7b mutant $\left(Z b t b 7 b^{R 367 Q}\right)$, or ThPOK knockout (ThPOKGFP/GFP) mice; $50 \mu \mathrm{g}$ of total protein was analyzed by immunoblotting (IB) for the expression of ThPOK protein. Molecular mass markers are indicated, with beta-actin used as a loading control.

highly similar to the previously described motif, NGGGGG(G/T)C, of the close family member ZBTB7A (LRF). The epigenetic status at the ThPOK binding site was analyzed by extracting the average histone posttranslational modification levels from published data sets for Th1 polarized CD4 ${ }^{+}$T cells $(30,31)$; in general, ThPOK binding is located at sites of open and active chromatin marked by H3K4me1 and H3K27Ac but where the repressive H3K27me3 mark is relatively absent (Fig. 3D). Gene ontology (GO) analysis for biological processes was performed on the single gene nearest to ThPOK binding peaks. The top biological processes identified by GO analysis were involved with $\mathrm{T}$ cell differentiation, $T$ cell activation, and other processes associated with gene transcription and transcriptional regulation (Fig. 3E); this suggest a critical role of ThPOK in the function of polarized Th1 cells.

ThPOK has been previously shown to control expression of the Runx3 gene, a major regulator of the ontogeny of T cells (32). ChIP-seq confirmed the presence of a ThPOK 
A

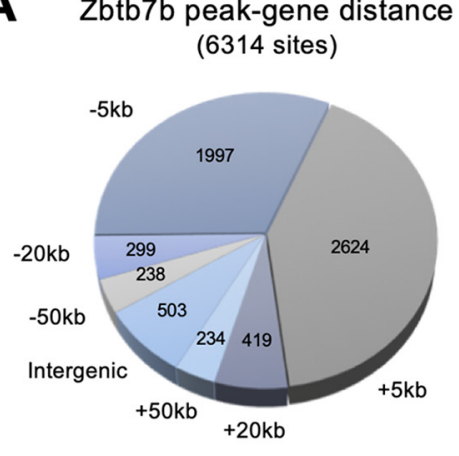

B

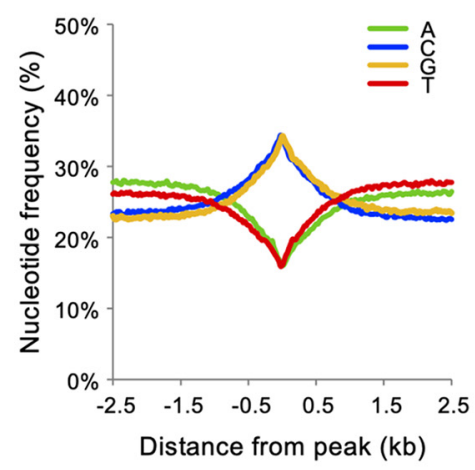

C

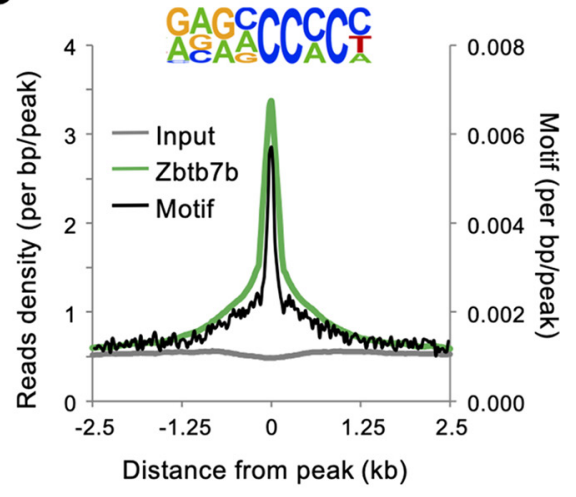

E Zbtb7b bound genes $\mathrm{GO}$ categories

D

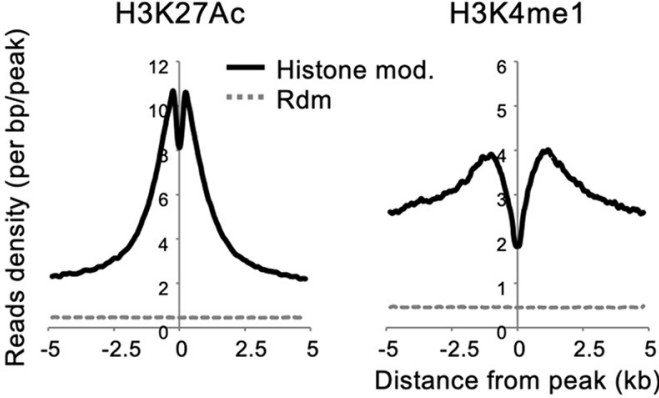

H3K27me3

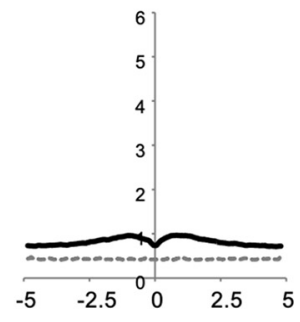

$\mathbf{F}$

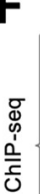

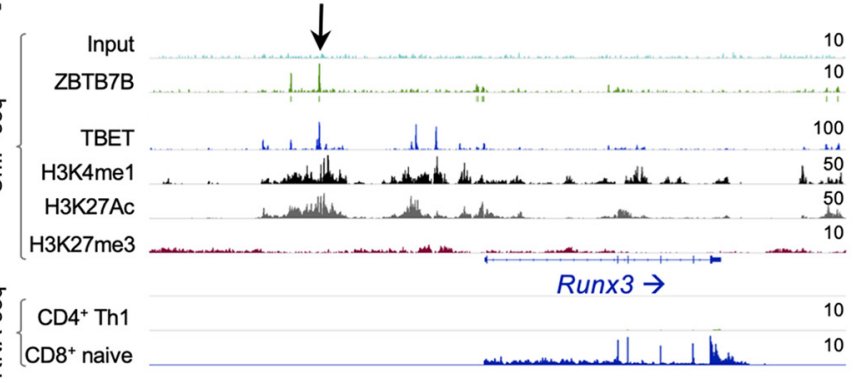

G

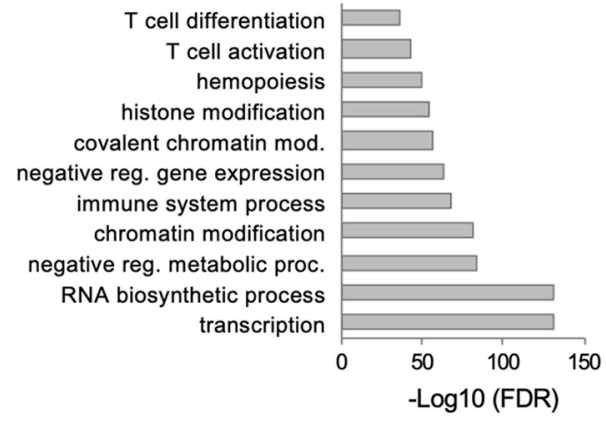

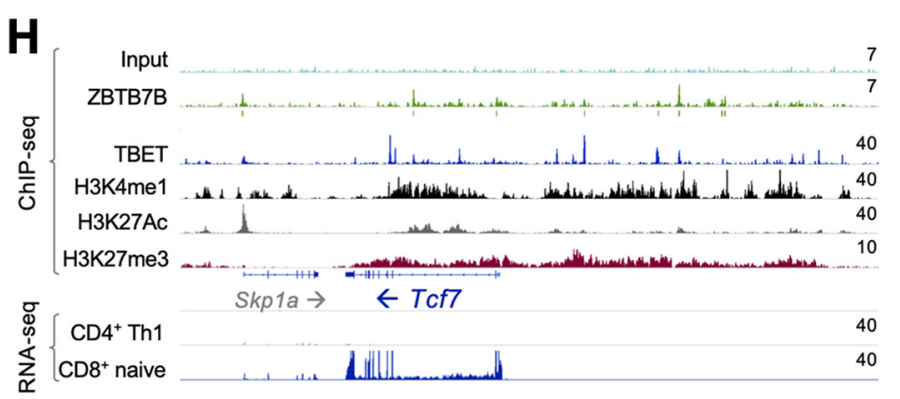
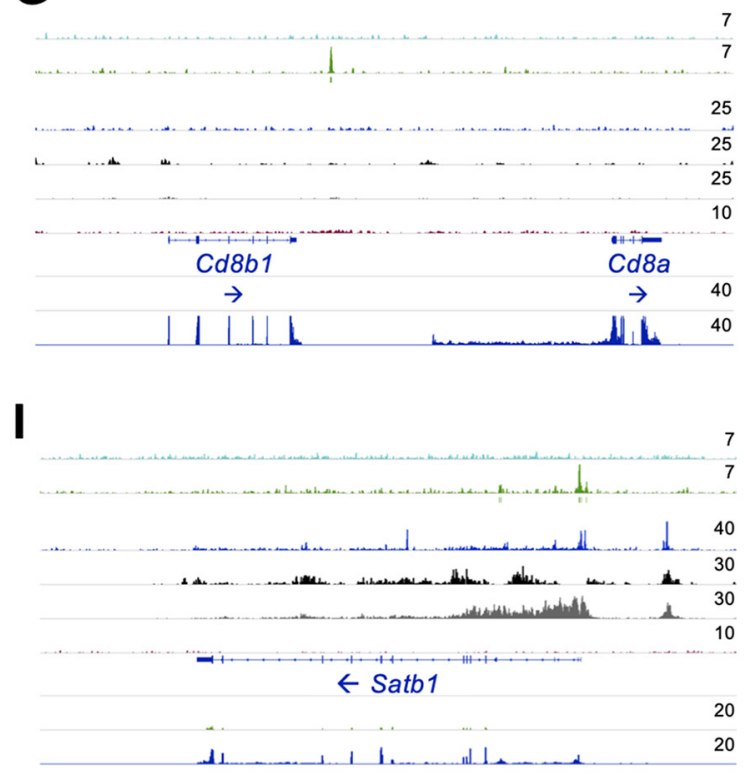

FIG 3 ThPOK cistrome in CD4 ${ }^{+} \mathrm{T}$ cells. ChIP-seq for ThPOK was performed using chromatin from in vitro-polarized Th1 primary CD4 ${ }^{+} \mathrm{T}$ cells. (A) ThPOK is recruited to 6,314 genomic sites; the position relative to the closest gene TSS is shown by category. Most ThPOK binding sites (73\%) are located within $\pm 5 \mathrm{~kb}$ of a known TSS. (B) Nucleotide frequencies at ThPOK ChIP-seq peaks. (C) Graph showing the average ThPOK (green curve) ChIP-seq sequence read density (enrichment) in comparison to the background signal (input; gray curve) at ThPOK binding sites. De novo motif-finding analysis was performed on $200 \mathrm{bp}$ of DNA sequence centered at the ThPOK binding peaks to identify the most prevalent motif. The most enriched motif $\left(P=1 \times 10^{-189}\right)$ is highly similar to the previously described ZBTB7A binding motif. The ThPOK motif and its relative position (black line) relative the ChIP-seq peak center are shown. (D) Graph showing the levels of H3K27Ac, H3K4me1, and K3K27me3 histone posttranslation modifications at ThPOK binding peaks in comparison to levels at randomly selected genomic regions (RDM). (E) Gene Ontology biological process enrichment analysis for the single nearest gene to a ThPOK peak. The top and nonredundant biological processes are shown, with the $-\log _{10}$ value of their binomial FDRs as calculated by GREAT. (F) Genomic snapshot of the Runx3 locus showing density of ChIP-seq read tracks for input control, ThPOK, T-bet, and epigenetic modifications H3K4me1, H3K27Ac, and H3K27me3; the arrow is pointing at the known ThPOK repressor site located at $-40 \mathrm{~kb}$ from the Runx3 TSS. Normalized gene expression profiles from $\mathrm{CD}^{+}{ }^{+} \mathrm{Th} 1$ cells and $\mathrm{CD} 8^{+}$naive $\mathrm{T}$ cells are shown. (G to I) Examples of ThPOK-bound loci containing genes implicated in $\mathrm{T}$ cell differentiation and maturation ( $C d 8, T c f 7$, and Satb1). 
A
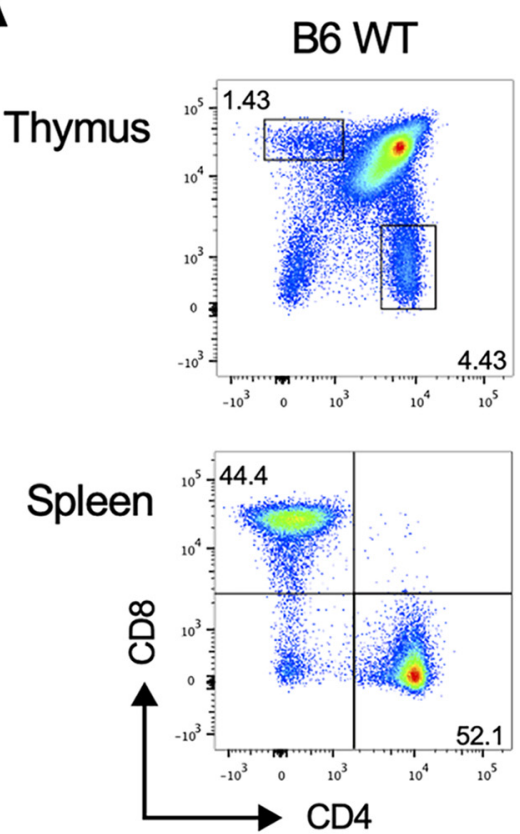

Zbtb7bR367Q
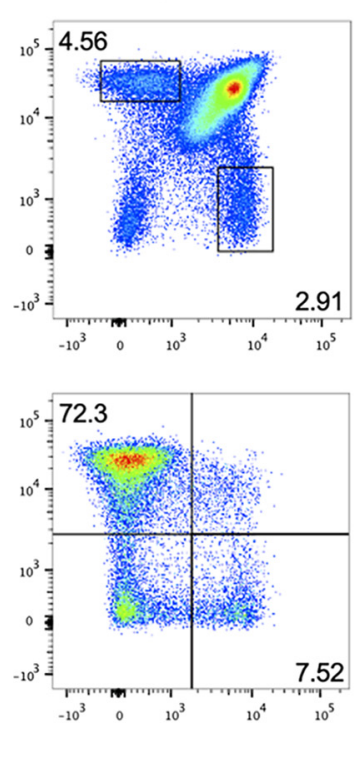

B
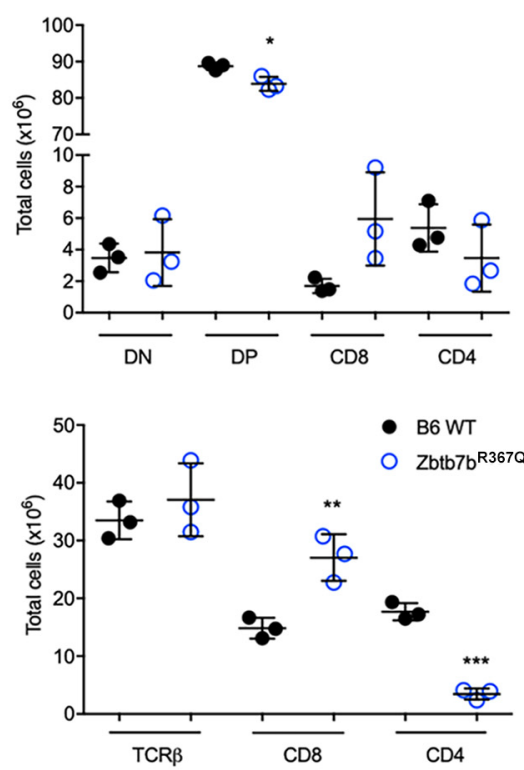

FIG 4 Zbtb7b $b^{R 3670}$ mice have a defect in thymic development, with reduced CD4 ${ }^{+} \mathrm{T}$ cell numbers. Primary thymocytes and splenocytes isolated from wild-type (B6) and mutant (Zbtb7b ${ }^{R 3670}$ ) mice were analyzed by FACS. (A) Representative FACS plots showing CD4 versus CD8 expression in thymocytes (top) and splenocytes (bottom). The numbers in the quadrants represent the percentages of parent CD45 cells. (B) Total numbers of T cell populations from the thymus and spleen ( $n=3$ for all experiments; the data are representative of 2 or more experiments). The data are represented as means \pm standard deviations (SD). The results were considered significant at a $P$ value of $<0.05$ when B6 WT was compared to Zbtb7b ${ }^{R 3670}$ mutants using a two-tailed Student's $t$ test $\left({ }^{*}, P<0.05 ;{ }^{* *}, P<0.01 ;{ }^{* * *}, P<0.001\right)$.

binding peak at a known regulatory region of Runx3 transcription located at $-40 \mathrm{~kb}$ upstream of the transcriptional start site (TSS) (Fig. 3F) (33). This site harbored marks of a transcriptionally active (H3K27Ac) enhancer (H3K4me1) and is concomitantly bound by T-bet, another transcription factor known to be involved in the ontogeny and activation of lymphoid cells and in driving Th1 polarization in response to infectious and inflammatory stimuli (Fig. 3F). The recruitment of ThPOK to this known regulatory site was to antagonize the activity of the site, thus blocking the expression of the nearby Runx3 gene, as shown by RNA sequencing (RNA-seq) expression in $\mathrm{CD}^{+}$naive T cells, but not in $\mathrm{CD}^{+}{ }^{+}$Th1 cells (Fig. 3F). Our ChIP-seq also identified a similar ThPOKT-bet-bound site at $-47 \mathrm{~kb}$ upstream of the Runx3 TSS that was previously undescribed. Scrutiny of the genome-wide data sets in Table S1 identified ThPOK binding sites in a number of CD8 T cell-expressed genes, in which loss of transcriptional repression may have an impact on the number and/or function of T lymphocytes (Fig. $3 \mathrm{G}$ to I) or T cell subsets. Indeed, a very strong ThPOK binding peak was detected in the Cd8 genes themselves, but also in genes previously involved in T cell differentiation (Tcf7) and in chromatin structure and regulation, including $T$ cell maturation (Satb1) (Fig. $3 \mathrm{G}$ to I).

Zbtb7b ${ }^{R 3670}$ mutant animals lack $\mathrm{CD}^{+}{ }^{+} \mathrm{T}$ cells and are protected from ECM pathogenesis. ThPOK is a transcription factor previously shown to be required for CD4 lineage commitment during positive thymocyte selection in the thymus (34). To monitor a possible impact of the R367Q mutation on T lymphocyte development, we carried out immunophenotyping on WT and $Z b t b 7 b^{R 367 Q}$ mutant mice either at steady state or following infection with $P$. berghei during ECM. Fluorescence-activated cell sorter (FACS) analysis of thymocytes and splenocytes from WT and Zbtb7b ${ }^{R 3670}$ mutant animals identified reduced numbers and proportions of singly positive $C D 4^{+} T$ cells in spleens and thymuses of the mutant mice at steady state, which was concomitant with increased numbers and proportions of single-positive $\mathrm{CD} 8^{+} \mathrm{T}$ cells and a decrease in the number of double-positive $\mathrm{CD} 4^{+} \mathrm{CD} 8^{+} \mathrm{T}$ cells in the thymus (Fig. $4 \mathrm{~A}$ and $\mathrm{B}$ ). The 
Zbtb7b ${ }^{R 367 Q}$ mutation did not impact the number of myeloid or NK cells in the spleen (data not shown).

We further investigated the impact of the $Z b t b 7 b^{R 367 Q}$ mutation on $T$ cells function during $P$. berghei infection. At day 5 postinfection, mutants showed deviations in numbers and proportions of singly positive $\mathrm{CD}^{+}$(decreased) and $\mathrm{CD}^{+}$(increased) $\mathrm{T}$ cells similar to those at steady state (Fig. $5 \mathrm{~A}$ and $\mathrm{B}$ ). This was concomitant with reduced IFN- $\gamma$ and TNF- $\alpha$ production by mutant splenocytes in vitro either in response to cross-linking of the $\mathrm{T}$ cell receptor with anti-CD3/CD28 antibodies or following incubation with phorbol myristate acetate (PMA) and ionomycin and as measured by enzyme-linked immunosorbent assay (ELISA) (Fig. 5C). Similarly, FACS analysis also identified a major reduction in the number of anti-IFN- $\gamma$ - or anti-TNF- $\alpha$-producing $\mathrm{CD}^{+} \mathrm{T}$ cells in the mutant. In addition, both the CD8 ${ }^{+} \mathrm{T}$ cells and the few CD4 ${ }^{+} \mathrm{T}$ cells present in the mutant were capable of producing IFN- $\gamma$ and TNF- $\alpha$ (Fig. 5D to F), indicating that the reduction in the number of $\mathrm{CD} 4^{+} \mathrm{T}$ cells in the mutant is responsible for the overall decrease in total cytokine production (Fig. 5E and F).

Pathogenesis in the ECM model is associated in part with local inflammatory reaction in response to trapped parasitized erythrocytes in the brain microvasculature with resulting breakdown of BBB integrity, associated with infiltration of inflammatory myeloid and lymphoid cells in situ. We assessed the impact of the $Z b t b 7 b^{R 367 Q}$ mutation on the integrity of the BBB during peak infection (day 6 p.i., including infiltration of inflammatory cells. For this, P. berghei ANKA-infected WT and mutant mice were perfused with phosphate-buffered saline (PBS), and their brains were harvested and analyzed for possible cellular infiltrates by flow cytometry. As opposed to typical infiltrates seen in WT mice at day 5 postinfection, $Z b t b 7 b^{R 367 Q}$ mutants showed very little infiltration of total CD45 hi leukocytes, including $\mathrm{CD}^{+}{ }^{+}$and $\mathrm{CD} 8^{+} \mathrm{T}$ cells, as well as CD $11 b^{+}$Ly6C $^{+}$myeloid cells (Fig. 5G), which together suggested that the BBB was intact in the mutants, in agreement with the ECM resistance in the mice.

Taken together, these results suggest that the $Z b t b 7 b^{R 367 Q}$ mutation causes a severe reduction in the number of $C D 4^{+} \mathrm{T}$ cells at steady state and under inflammatory stimuli, which results in reduced production of proinflammatory cytokines and protection against lethal neuroinflammation.

Zbtb7b ${ }^{R 367 Q}$ mutant animals show increased susceptibility to mycobacterial infection. IFN- $\gamma$-mediated activation of infected myeloid cells is critical for elimination of intracellular mycobacteria, and Th1 polarized CD4 ${ }^{+} \mathrm{T}$ cells represent a major source of IFN- $\gamma$ in vivo (35). Hence, we first measured the response of $Z b t b 7 b^{R 367 Q}$ mutant mice to infection with avirulent $M$. bovis BCG, as assessed by the presence and extent of splenomegaly and bacterial replication in the spleen at the peak of infection (3 weeks) and during the curative phase ( 6 weeks). At 3 weeks postinfection, there was significant splenomegaly in both WT and mutant mice, with parallel and comparable replication of BCG in the spleens of both mutants and controls (Fig. $6 \mathrm{~A}$ and B). However, at 6 weeks postinfection, a time at which immune-response-dependent clearance of the bacterial load occurs, the $Z b t b 7 b^{R 367 Q}$ mutant mice showed significantly higher spleen CFU counts than their WT counterparts, by a factor of 8-fold, indicating reduced ability to clear the BCG load from the spleen (Fig. 6A). The presence of an increased bacterial load in mutant animals coincided with significant splenomegaly (Fig. 6B).

We then tested the susceptibility of $Z b t b 7 b^{R 367 Q}$ mutant mice to pulmonary tuberculosis induced by aerosol infection with low-dose virulent M. tuberculosis H37Rv. The bacterial burden was measured in the lung at days 30 and 60 postinfection, and survival was monitored. Infected $Z b t b 7 b^{R 367 Q}$ mutant animals showed increased mortality compared to wild-type animals (mean survival time, $\sim 150$ days versus $>250$ days for controls) (Fig. 6C). Decreased survival in the mutants was associated with increased bacillary burden at day 60 postinfection (Fig. 6D), which was concomitant with significant cellular infiltrates (Fig. 6E) consisting of both myeloid and lymphoid cells (data not shown). Hematoxylin and eosin (H\&E) staining of fixed sections of lungs from infected $Z b t b 7 b^{R 367 Q}$ mutant animals showed severe disruption of the lung alveolar network associated with massive infiltration of leukocytes and areas of necrosis (Fig. 6F); Zbtb7b $b^{R 367 Q}$ 
A

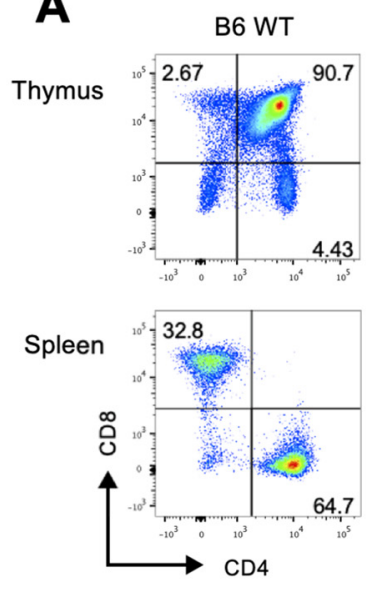

D
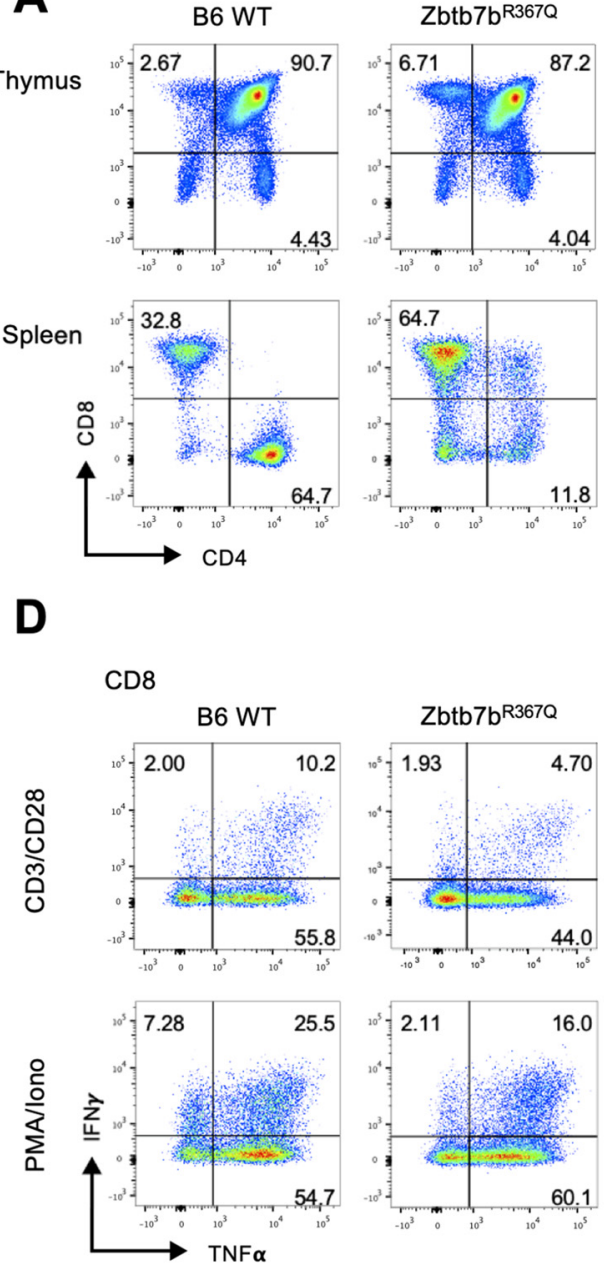

B

E
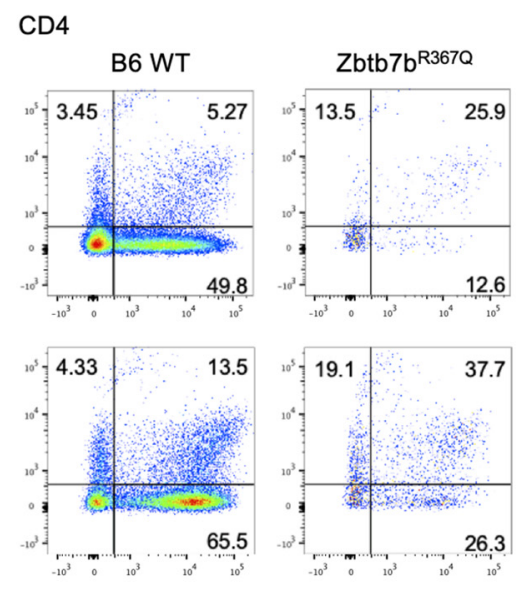

C
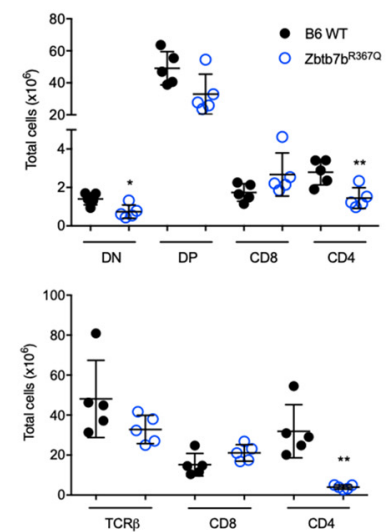
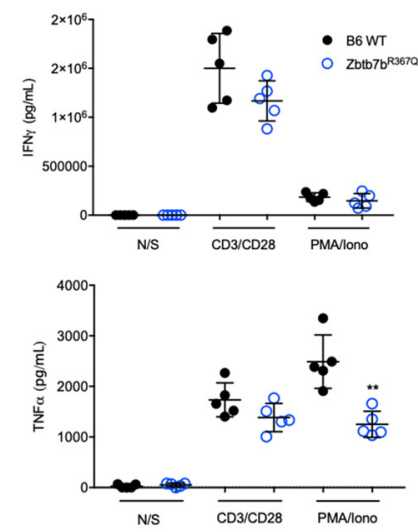

F
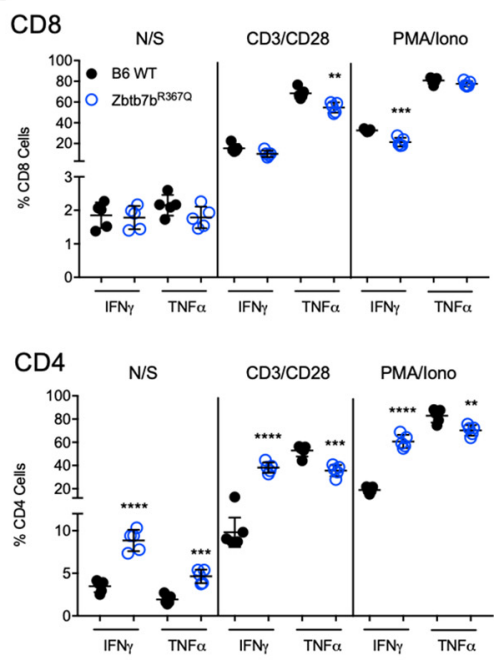

G

B6 WT
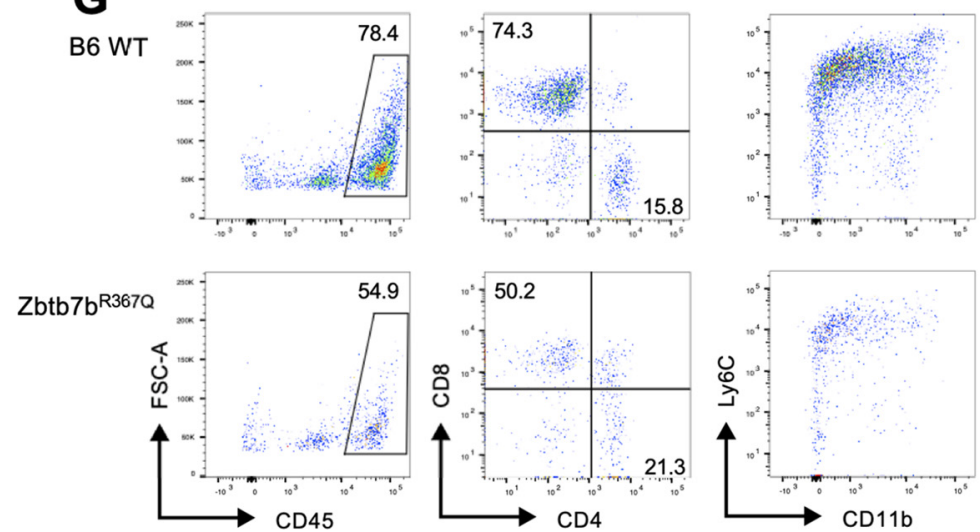

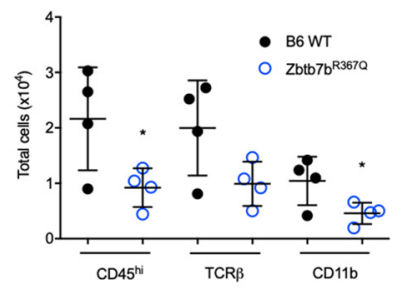

FIG 5 Immunophenotyping of Zbtb7b ${ }^{R 3670}$ mutant mice following infection with $P$. berghei ANKA. (A and B) Wild-type (B6) and mutant $Z b t b 7 b^{R 3670}$ mice were infected with $10^{6} \mathrm{P}$. berghei ANKA pRBCs, and thymocytes and splenocytes were isolated and analyzed at day 5 postinfection. $\mathrm{CD}^{+}$versus $\mathrm{CD} 8^{+} \mathrm{T}$ cells were stained, analyzed by FACS (A), and quantified (B). (C) Splenocytes from infected mice were cultured for $24 \mathrm{~h}$ with either anti-CD3/anti-CD28 or PMA and ionomycin (Iono), and cytokines were measured in cell supernatants by ELISA. (D and E) T cells from infected mice were similarly stimulated for $6 \mathrm{~h}$, followed by intracellular staining for IFN- $\gamma$ and TNF- $\alpha$ as determined by FACS. (F) Results were quantified and expressed as percentages of CD8 (D) or CD4 (E) T cells that were positive for IFN- $\gamma$, TNF- $\alpha$, or both. (G) Six days after infection with $P$. berghei ANKA, brains from wild-type and mutant mice were perfused, and infiltrating leukocytes were isolated and analyzed by FACS. Representative FACS plots of infiltrating CD45 hi leukocytes, CD4 ${ }^{+}$and CD8 ${ }^{+} \mathrm{T}$ cells, and CD11 $\mathrm{b}^{+}$ $\mathrm{Ly}_{6 \mathrm{C}}{ }^{+}$myeloid cells are shown. The results were considered significant at a $P$ value of $<0.05$ when B6 WT mice were compared to $Z b t b 7 b^{R 3670}$ mutants using a two-tailed Student $t$ test $\left({ }^{*}, P<0.05 ;{ }^{* *}, P<0.01 ;{ }^{* * *}, P<0.001 ;{ }^{* * * *}, P<0.0001\right)$. 
A

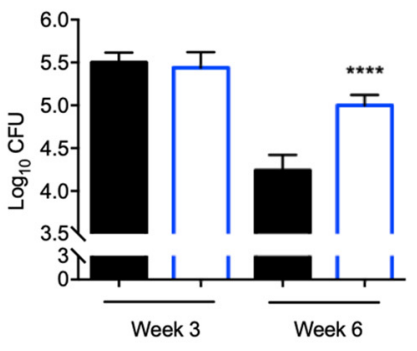

C

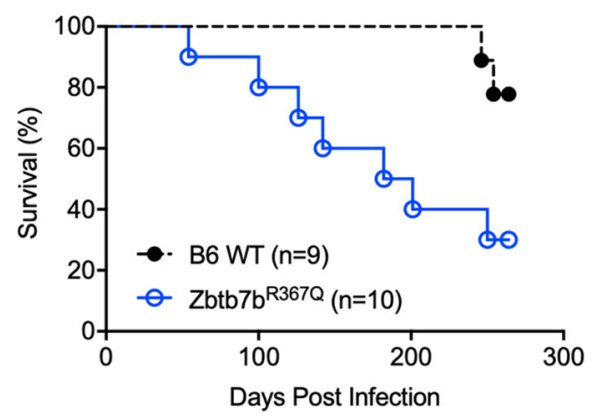

B

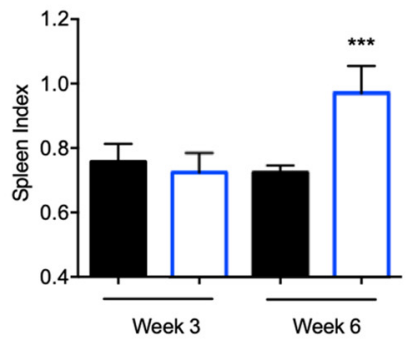

D

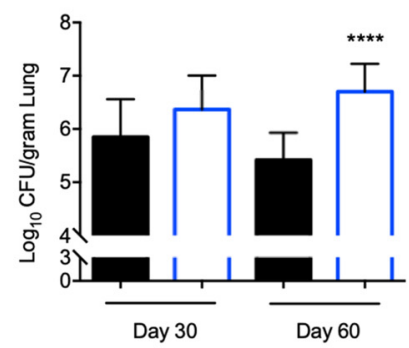

E

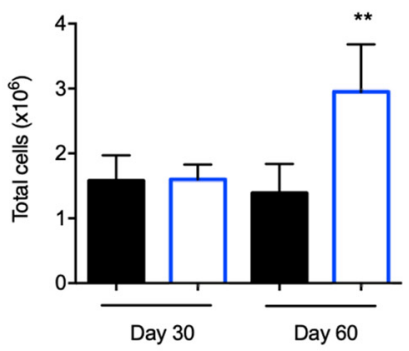

F
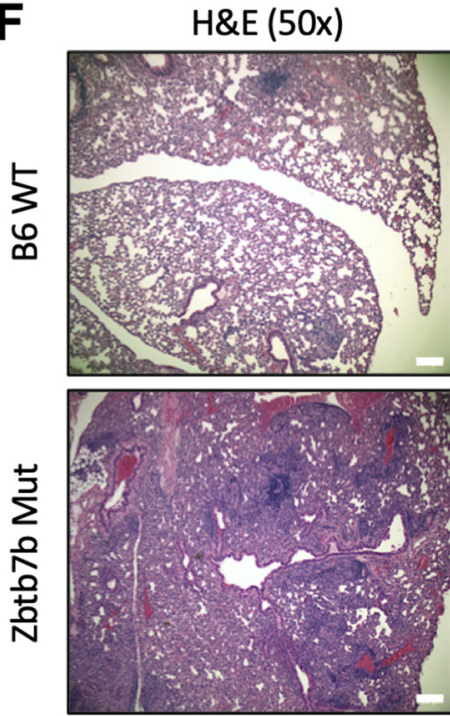

H\&E (100x)
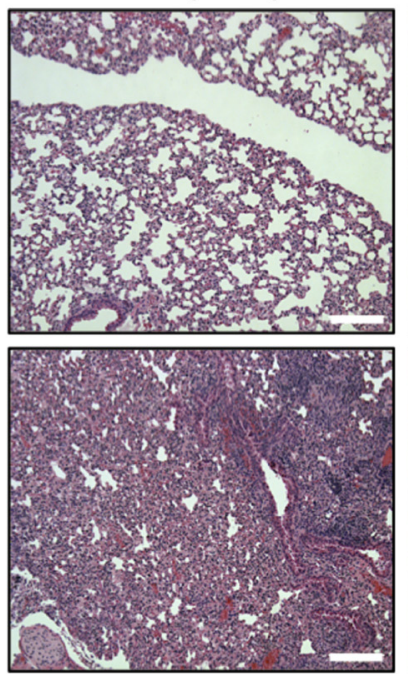
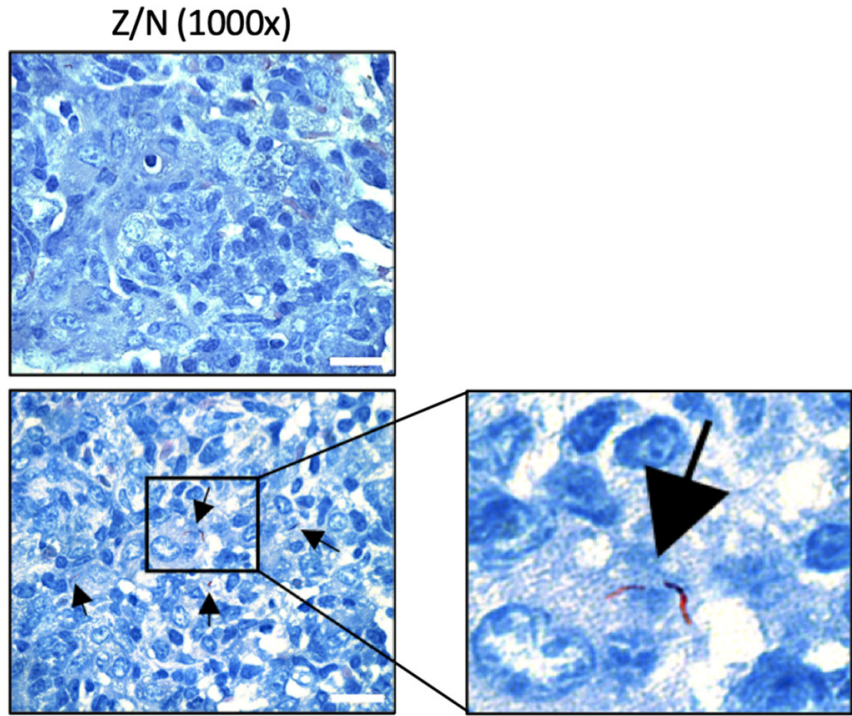

FIG 6 Zbtb7b $b^{R 367 Q}$ mutant response to mycobacterial infection. Wild-type (B6) and mutant Zbtb7b $b^{R 367 Q}$ mice were infected with $5 \times 10^{4}$ CFU of live BCG. (A and B) Spleens were isolated, and bacterial load (A) and spleen index (B) were determined 3 and 6 weeks postinfection. (C) Mice were infected with $\sim 50$ CFU of M. tuberculosis H37Rv via aerosol inhalation, and survival was monitored ( $n=10)$. (D) Lungs were perfused and homogenized at days 30 and 60 postinfection, and bacterial counts were determined. (E) The total numbers of infiltrating cells in the lungs were determined at days 30 and 60 postinfection ( $n=5$ mice unless otherwise noted). The data are from 1 experiment and are shown as means and SD. (F) Histological analysis was performed on infected lungs at day 60 postinfection by H\&E staining and Ziehl-Neelsen staining for acid-fast bacilli. The results were considered significant at a $P$ value of $<0.05$ when B6 WT mice were compared to $Z b t b 7 b^{R 367 Q}$ mutants using a two-tailed Student $t$ test. $\left({ }^{* *}, P<0.01\right.$; $\left.{ }^{* * *}, P<0.001\right)$.

mice have normal lung morphology at steady state (not shown). The higher bacterial burden in the lungs of infected Zbtb7bR367Q mutant animals was also obvious by ZiehlNeelsen staining for acid-fast bacilli, even early during infection (day 60).

Together, these results show that inactivation of $Z b t b 7 b$ causes susceptibility to mycobacterial infections.

\section{DISCUSSION}

Phenotype-driven ENU mutagenesis screening in mice infected with P. berghei ANKA to identify recessive mutations that protect against lethality in this model of cerebral 
malaria has been effective in identifying genes and pathways required for normal inflammatory responses but whose sustained activation leads to pathological inflammation $(8,19-21,23)$. The screen has detected genes required for the development (Themis/Lck, T-cell receptor complex subunits; FoxN1, transcription factor; Jak3, tyrosine kinase) and activity (Lyst, lysosomal constituent) of lymphoid cells, but also myeloid cells (Irf8, myeloid cell development; Ccdc88b, cell mobility; Usp15/Trim25, type I interferon signaling). Several of the genes identified in the screen have also been detected as risk loci for human chronic inflammatory diseases and/or are mutated in certain human primary immunodeficiencies (36-38).

Here, we report a novel ENU-induced mutation in Zbtb7b (Zbtb7b $\left.{ }^{R 367 Q}\right)$ that causes ECM resistance in $P$. berghei ANKA-infected mice. ThPOK (27) is a transcription factor of the $\mathrm{Zn}$ finger and BTB domain-containing (ZBTB) family, and the R367Q mutation maps to the first of 4 zinc finger domains of the protein at a residue that makes base contacts in the major groove of DNA. Protein modeling indicated that these base contacts are lost in the Q367 variant, strongly suggesting that the mutation causes loss of DNA binding by ThPOK. Zbtb7b $b^{R 367 Q}$ mutant mice show a defect in T cell maturation, with severely reduced numbers of peripheral $\mathrm{CD} 4^{+} \mathrm{T}$ cells, that is associated with reduced production of proinflammatory cytokines in vivo upon infectious and inflammatory insults or in primary $\mathrm{T}$ cells cultured in vitro and stimulated either nonspecifically or following TCR engagement. This defect in $\mathrm{CD}^{+} \mathrm{T}$ cells and the associated impaired inflammatory response in the $Z b t b 7 b^{R 367 Q}$ mutant are concomitant with increased susceptibility to infection with intracellular pathogens, namely, M. bovis and $M$. tuberculosis. For M. tuberculosis, susceptibility is evidenced by an increased microbial load in the lungs and severe lung pathology and is associated with predominant infiltration of inflammatory cells and overall reduced survival.

The intrathymic development of $\mathrm{CD}^{+}$and $\mathrm{CD}^{+} \mathrm{T}$ cells relies on sequential transcriptional activation and silencing of a number of cellular programs associated with cell division, apoptosis, and expression of lineage-specific functions. Doublepositive thymocytes differentiate into single-positive $\mathrm{CD}^{+}$or $\mathrm{CD} 8^{+}$cells, which is dependent on TCR engagement by self-peptide molecules on MHC class I/II molecules. Class I-restricted cells undergo the CD8 lineage fate, while class II-restricted cells are committed to the CD4 lineage (14). Mutations in genes encoding proteins important for DNA replication, recombination and repair (RAG1/2, LIGA, ADA, and PRKDC), T cell receptor signaling (CD3 chains, LAT, LCK, and THEMIS), and transcriptional regulation (RUNX3, FOXN1, MYSM1, RELB, GATA1, and ZBTB24) all cause immunodeficiencies, with severe lymphopenia in humans $(37,38)$. Zbtb7b has been previously reported to be important for $\mathrm{CD}^{+}{ }^{+} \mathrm{T}$ cell differentiation in the thymus, with the helper-deficient (HD) mutation affecting the second zinc finger (14) and the complete knockout showing a selective absence in $\mathrm{CD}^{+}{ }^{+} \mathrm{T}$ cells and a reciprocal increase in $\mathrm{CD} 8^{+} \mathrm{T}$ cells. In class I-restricted cells, the transcription factor Runx3 is upregulated and promotes the termination of CD4 expression during CD8 differentiation. ThPOK is expressed in class Il-restricted cells and represses Runx3 activity, allowing expression of the CD4 lineage. While loss of ThPOK expression in class II-restricted thymocytes redirects CD4 ${ }^{+} \mathrm{T}$ cells to the $\mathrm{CD}^{+}$lineage (27), forced ThPOK expression in class I-restricted CD8 ${ }^{+}$cells promotes conversion to the CD4+ lineage $(27,29)$. ThPOK mediates silencing of Runx3 expression through direct binding of ZBTB7B/ThPOK to the major enhancer of the Runx3 gene located $\sim 40 \mathrm{~kb}$ upstream of the transcription start site of Runx3 (33).

Although the role of ThPOK in Runx3 expression has been well described, the more global role of ThPOK as a transcriptional repressor in T cell development has not yet been systematically studied. We used ChIP-seq to identify other binding sites of ThPOK and associated genes whose repression may be relevant to $T$ cell development and function and to infectious and inflammatory diseases in humans. In this analysis, the relevance of the ChIP-seq data obtained is highlighted by the finding that the Runx3 enhancer (at $-40 \mathrm{~kb}$ ) is the most enriched site of ThPOK binding in Th1 cells genomewide. Interestingly, a new ThPOK binding site was detected further upstream (at -47 kb), suggesting that ThPOK represses two Runx3 enhancers in Th1 cells. These exper- 
iments suggest that ThPOK-mediated repression of Runx3 enhancers persists well after T cells have committed to the CD4 lineage. This repressive nature of ThPOK in mature cells is supported by the observation that ThPOK acts as a negative regulator of the CD8 lineage by silencing $C d 8$ genes during $\operatorname{CD} 4$ differentiation $(27,29,39,40)$ while antagonizing RUNX3 activity by binding to the $C d 4$ silencer region, as well as silencer regions on the Zbtb7b gene itself (40). Indeed, our ChIP-seq analysis detected a major binding peak in the regulatory region of the $C d 8$ genes, in agreement with a silencing role of ThPOK in $C d 8$ gene expression. Inactivation of $C d 8$ in mice causes a significant $T$ cell deficiency, with concomitant appearance of resistance to cerebral malaria and susceptibility to pulmonary TB (8), in agreement with the phenotype of Zbtb7b mutant mice tested here. In addition, loss-of-function mutations (autosomal recessive) in the human CD8 gene or alterations in $\mathrm{CD}^{+} \mathrm{T}$ cell numbers and function are associated with recurring infections and impaired antibody responses (37).

On the other hand, RUNX3 plays a critical role in additional immune functions whose impairment is associated with disease. Inactivation of Runx3 in mice not only causes T cell defects in knockout mice, but also causes absence of Langerhans cells (41) and is associated with chronic inflammation of the lung (asthma) (42), skin (psoriasis) (43), and digestive tract (colonic and gastric mucosa) $(44,45)$. In humans, genetic variants near or at the RUNX3 gene are associated with inflammatory bowel diseases and are responsible for the IBD7 locus mapped in genome-wide association studies (46). While the $Z b t b 7 b$ locus itself had a suggestive association with asthma (42) and was associated with eczema (47), it is tempting to speculate that modulation of human ZBTB7B function (coding or regulatory variants) may impact RUNX3 expression and possibly inflammatory disease susceptibility in humans.

Our studies have also identified a novel role of ThPOK in regulating expression of gene targets critical for $\mathrm{T}$ cell development and function and whose alteration is linked to human diseases. For example, TCF7 is a member of the TCF-LEF family of transcription factors and is abundantly expressed in developing thymocytes during negative selection (48); TCF7 interacts with RUNX3 to silence Cd4 during CD8 lineage commitment, suggesting another regulatory site of ThPOK function in the development of $T$ cells (48). Our ChIP-seq studies also uncovered another regulatory site for ThPOK at the special AT-rich binding protein 1 gene (Satb1), which codes for a nuclear protein that binds to matrix attachment regions of DNA and that functions as a genome organizer in modifying chromatin structure. Satb1 mutant mice have a small thymus and spleen and have a severe reduction of $\mathrm{CD}^{-} \mathrm{CD}^{-}{ }^{-} \mathrm{CD} 8^{-}$triple-negative thymocytes, as well as reduced numbers of mature thymocytes (49). SATB1 was recently found to play a critical role in lymphocyte development by activating genes such as Runx3, Cd4, and Cd8 in T cells following thymic selection (50). SATB1 is also required for the production of Foxp $3^{+}$regulatory T cells (51). In humans, SATB1 has been implicated in the pathogenesis of the leukemia form of T cell lymphoma, Sézary syndrome (52). Genetic variants near or at SATB1 are linked to chronic mucus secretion syndrome, a reaction to chronic inflammation of the lung (53).

Taken together, our studies provide novel insight into the role of ThPOK in the global development of $\mathrm{T}$ cells, identifying a role for the transcriptional repressor in the known regulatory network of $\mathrm{T}$ cell maturation in the thymus. They also suggest that ThPOK may play a broader role by regulating other gene targets in these pathways, but also in the etiology of certain infectious and inflammatory diseases in humans.

\section{MATERIALS AND METHODS}

Ethics statement. This study was performed under the guidelines of the Canadian Council on Animal Care. Animal use protocols were approved by the ethics committee of McGill University (protocol no. 5287). Mice were anesthetized with isoflurane and euthanized by carbon dioxide inhalation. Every effort was made to minimize animal suffering.

Mice. Inbred B6 mice were purchased from the Jackson Laboratory and maintained under specificpathogen-free conditions at the animal care facility of the Goodman Cancer Research Centre (McGill University). ENU mutagenesis to identify recessive mutations that cause resistance to $P$. berghei-induced cerebral malaria (ECM) was performed according to a mutagenesis and breeding strategy we have previously described (20) (Fig. 1A). Briefly, mutagenized G0 B6 males were crossed to B6 WT females to 
generate G1 offspring, which were then outcrossed to B6 WT females to generate a G2 generation. Two G2 females (Lesley and Addyson) were backcrossed to a G1 male (Farris) to generate G3 mice, which were systematically phenotyped for susceptibility to ECM. Zbtb7b $2367 \mathrm{Q} /+$ heterozygotes were intercrossed to generate a pure $Z b t b 7 b^{R 367 Q}$ homozygote line. The ThPOKGFP/GFP mice were from Ichiro Taniuchi and were generated as previously described (40).

Parasites and infections. $P$. berghei ANKA parasites were obtained from the Malaria Reference and Research Reagent Resource Center (MR4). The parasites were maintained as frozen stocks at $-80^{\circ} \mathrm{C}$ and passaged weekly in adult B6 WT mice. Blood parasitemia was determined by blood smears and staining with Diff-Quick reagents (Dade Behring, Newark, DE, USA). Seven- to 8-week-old mice were infected intravenously (i.v.) with $10^{6} \mathrm{pRBC}$ and monitored three times daily for signs of neurological symptoms. Mice experiencing cerebral symptoms were euthanized, and mice surviving past day 13 were considered ECM resistant and euthanized at day 20 postinfection (the experimental endpoint).

Whole-exome sequencing. Whole-exome sequencing was performed on 3 ECM-resistant Farris G3 mice. Exome capture was performed using a SureSelect Mouse All Exon kit (Agilent Technologies), and DNA libraries were sequenced on an Illumina HiSeq 2000 (100-bp paired-end reads). The reads were then aligned to the reference mouse genome assembly (NCBI37/mm9) with the Burrows-Wheeler alignment tool (54), and coverage was assessed with BED-Tools (55). Single-nucleotide variants were called using the Samtools pileup and varFilter (54) and then quality filtered to require at least $20 \%$ of reads to support the variant call. Variants were annotated with ANNOVAR (56). The Zbtb7b $b^{R 367 Q}$ mutation was genotyped by PCR amplification $\left(5^{\prime}-\mathrm{TC}\right.$ TTGGGAACTAGCCCACTC-3' and 5'-CCTCGCTATCACCAGAGGAG-3'), followed by sequencing.

Immunophenotyping. Mice were sacrificed either prior to infection or 5 days postinfection, at which point spleens were removed and placed in cold RPMI containing 3\% fetal bovine serum (FBS) and 2\% penicillin-streptomycin. Single-cell suspensions were prepared, and red blood cells were lysed in lysis buffer (155 mM NH $\mathrm{mM}_{4} \mathrm{Cl} 12 \mathrm{mM} \mathrm{NaHCO}, 0.1 \mathrm{mM}$ EDTA). The cells were washed and plated at $2 \times 10^{6}$ cells/well in a 96-well plate for staining in FACS buffer (PBS, 2\% FBS). The cells were surface stained for $30 \mathrm{~min}$ at $4^{\circ} \mathrm{C}$ with the following antibody cocktail: allophycocyanin (APC)-eFluor 780 anti-CD45 (30-F11), phycoerythrin (PE) anti-CD8 $\alpha$ (53-6.7), peridinin chlorophyll protein (PerCP)-Cy 5.5 anti-CD4 (Rm4-5), and fluorescein isothiocyanate (FITC) TCR $\beta$ (H57-957). All the antibodies were from eBioscience unless otherwise stated. Viable cells were stained using the Zombie Aqua fixable viability kit (Biolegend) and then fixed using a fixation/permeabilization kit (BD Biosciences). The cells were analyzed with an eight-color FACS Canto II using FACS Diva software (BD Biosciences); the data were analyzed using FlowJo software (Tree Star). One hundred thousand cells were acquired per sample, and aggregates were removed based on forward scatter height (FSC-H) versus area (FSC-A). Live cells were determined by side scatter area (SSC-A) versus FSC-A, followed by live/dead gating, and leukocytes were isolated as CD45 ${ }^{+}$ cells. For intracellular-cytokine production, single-cell suspensions from spleens were either incubated at $37^{\circ} \mathrm{C}$ for $6 \mathrm{~h}$ in plates coated with anti-CD3 $(5 \mu \mathrm{g} / \mathrm{ml}$; eBioscience) and soluble anti-CD28 $(2 \mu \mathrm{g} / \mathrm{ml}$; eBioscience) antibodies or stimulated with PMA $(50 \mathrm{ng} / \mathrm{ml})$ and ionomycin $(500 \mathrm{ng} / \mathrm{ml})$. The cells were then incubated with the following antibody cocktail: PerCP-Cy 5.5 anti-CD4 (GK1.5) and APC-efluor 780 anti-CD8 $\alpha$ (53-6.7). After fixation, the cells were analyzed for intracellular cytokines with an antibody cocktail containing APC anti-TNF- $\alpha$ (MPG-XT22) and PE anti-IFN- $\gamma$ (XMG1.2) and analyzed by FACS.

Leukocytes infiltrating the brains of infected animals were isolated on day 6 postinfection as previously described (23). Infiltrating cells were incubated with the following antibody cocktails and analyzed by FACS: APC-eFluor 780 anti-CD45 (30-F11), PE anti-CD8 $\alpha$ (53-6.7), PerCP-Cy 5.5 anti-CD4 (Rm4-5), APC TCR $\beta$ (H57957), and eFluor 450 anti-CD19 (6D5) for lymphoid cells or APC-eFluor 780 anti-CD45 (30-F11), PE-Cy7 anti-CD11b (M1/70), PE anti-Ly6C (HK1.4), eFluor 450 anti-F4/80 (BM8), FITC anti-Ly6G (1A8), and PerCp-Cy5.5 anti-CD11c (N418) for myeloid cells. Splenocytes $\left(2 \times 10^{6}\right)$ were stimulated in complete RPMI medium at $37^{\circ} \mathrm{C}$ for 24 or $48 \mathrm{~h}$ with precoated anti-CD3 $(5 \mu \mathrm{g} / \mathrm{ml}$; eBioscience) and soluble anti-CD28 ( $2 \mu \mathrm{g} / \mathrm{ml}$; eBioscience) antibodies or with PMA $(50 \mathrm{ng} / \mathrm{ml})$ and ionomycin $(500 \mathrm{ng} / \mathrm{ml})$. The cell supernatants were collected, and IFN- $\gamma$ or TNF- $\alpha$ was measured by ELISA (BioLegend).

Western blotting. Spleens and thymuses from B6 WT, Zbtb7b ${ }^{R 367 Q}$, and ThPOKGFP/GFP mice were snap-frozen in liquid nitrogen and ground using a mortar and pestle on dry ice. The resulting ground tissues were lysed in modified RIPA buffer (50 mM Tris, pH 7.5, $150 \mathrm{mM} \mathrm{NaCl}, 1 \%$ Triton X-100, 0.1\% SDS, and the protease inhibitors aprotinin [20 $\mu \mathrm{g} / \mathrm{ml}]$, leupeptin $[10 \mu \mathrm{g} / \mathrm{ml}]$, pepstatin $[1 \mu \mathrm{g} / \mathrm{ml}]$, and phenylmethylsulfonyl fluoride [PMSF] [100 $\mu \mathrm{g} / \mathrm{ml}]$ ); homogenized using a 25-gauge (25G) needle; and clarified by centrifugation. Thirty micrograms of protein was subjected to SDS-PAGE and transferred to nitrocellulose membranes. The membranes were blocked in 5\% nonfat dry milk in TBS-T (TBS with $0.1 \%$ Tween) and then incubated with primary antibodies against ThPOK (BD Pharmingen; 565500; 1:100 dilution) and $\beta$-actin (EMD Millipore; MAB1501; 1:20,000 dilution). The membranes were then washed three times in TBS-T, followed by incubation with anti-rat horseradish peroxidase (HRP) (R\&D Systems; HAF005) or goat anti-mouse HRP (Cell Signaling Technology; 7076S) at 1:5,000 dilution. The membranes were developed using SuperSignal West Pico or Femto chemiluminescence reagent (ThermoScientific).

ChIP-seq. Th1 cells were obtained by isolating lymph nodes and spleens from B6 WT mice, and naive $\mathrm{CD}^{+} \mathrm{T}$ cells were enriched using the EasySep mouse naïve CD4 ${ }^{+} \mathrm{T}$ cell isolation kit (StemCell). The cells were polarized into the Th1 cells for 6 days using plate-bound anti-CD3 $(5 \mu \mathrm{g} / \mathrm{ml})$ in complete RPMI medium (RPMI-1610, 10\% FBS, $1 \times$ penicillin-streptomycin, and $1 \times$ nonessential amino acids) containing anti-CD28 (3 $\mu \mathrm{g} / \mathrm{ml}), \mathrm{IL}-12(10 \mathrm{ng} / \mathrm{ml}), \mathrm{IL}-2(10 \mathrm{ng} / \mathrm{ml})$, and anti-IL-4 $(10 \mu \mathrm{g} / \mathrm{ml})$, with the medium replenished after 3 days. Th1 polarization was assessed by staining the cells with eFluor450 anti-CD4 (GK1.5), PE anti-CD4 (IM-7), and APC anti-CD62L (MEL-14)) and analyzed by FACS. Th1 polarized cells were stimulated ( $2 \mathrm{~h}$ ) with anti-CD3 $(5 \mu \mathrm{g} / \mathrm{ml})$, anti-CD28 (3 $\mu \mathrm{g} / \mathrm{ml}), \mathrm{IL}-12(10 \mathrm{ng} / \mathrm{ml}), \mathrm{IL}-18(10 \mathrm{ng} / \mu \mathrm{l})$, and IFN- $\gamma$ $(400 \mathrm{U} / \mathrm{ml})$, and $10 \times 10^{6}$ cells were used per ChIP-seq experiment. ChIPs were performed as previously 
described (57) using the following antibodies: ThPOK (5 $\mu$ g; sc-79127X) from Santa Cruz Biotechnology and H3K27Ac ( $3 \mu \mathrm{g}$; ab4729) from Abcam. The ChIP-seq libraries were prepared using a Kapa ChIP library kit (Kapa Biosystems) and sequenced on a HiSeq 2500 (Illumina) using a 50-bp paired-end configuration, with sonicated input DNA as a control. The reads were mapped to the mouse $\mathrm{mm} 9$ reference genome with Bowtie 1.0.0 (58), and ThPOK binding sites were identified using the MACS 1.4.1 peak-finding algorithm (59), with comparisons for read enrichment against control input DNA (see Table S1A for the ThPOK peak list). Normalized sequence read density profiles (Bigwig file format) were generated with the Homer toolbox (60) and visualized with IGV (61). The Th1 cells' published ChIP-seq raw sequence reads were retrieved from the Gene Expression Omnibus (T-bet, GSM836124; H3K27Ac, GSM2389489; H3K27me3, GSM2389500; H3K4me1 GSM994512) (62) and analyzed as described above. To generate random sets of genomic sites, BED-Tools' random tool was used (55), and average sequencing read profiles were extracted at ThPOK peaks and random genomic regions using the Homer annotatePeaks tool (60). To define ThPOK-associated binding motifs, de novo motif analysis was performed on $200 \mathrm{bp}$ of DNA sequence surrounding the binding peak maxima of the ThPOK data set using the Homer findMotifGenome tool (60). The graphical representation of the position weight matrices was obtained using WebLogo (63). To determine if specific biological functions were enriched among genes in proximity to ThPOK binding sites, the genomic coordinates for each peak were submitted to the GREAT 2.0.2 tool (64). We used the single nearest gene association rule to identify genes potentially regulated by ThPOK binding. Representative GO (biological processes) categories were selected, annotation redundancies were excluded, and the resulting binomial false-discovery rate (FDR) $q$ values were $\log _{10}$ transformed (see Table S1B).

Mycobacterial infections. Single-cell suspensions of $M$. bovis BCG were prepared for in vivo infection as previously described (65). Briefly, $5 \times 10^{4}$ CFU was injected intravenously into 8 - to 12 -week-old WT and $Z b t b 7 b$ mutant mice. At 3 and 6 weeks postinfection, mice were sacrificed and weighed, and $M$. bovis BCG CFU in their spleens were determined by homogenization and plating on Dubos oleic agar base, followed by 3 weeks of incubation at $37^{\circ} \mathrm{C}$. Splenomegaly (the spleen index) was monitored; the spleen index is defined as the square root of the spleen weight (times 100) divided by the body weight. To measure cytokine production, splenocytes $\left(2 \times 10^{6}\right.$ cells) were stimulated in complete RPMI medium $\left(37^{\circ} \mathrm{C}\right.$ for 24 or $48 \mathrm{~h}$ ) with either precoated anti-CD3 $(5 \mu \mathrm{g} / \mathrm{ml}$; eBioscience) or soluble anti-CD28 ( $2 \mu \mathrm{g} / \mathrm{ml}$; eBioscience) antibodies and stimulated with PMA $(50 \mathrm{ng} / \mathrm{ml})$ and ionomycin $(500 \mathrm{ng} / \mathrm{ml})$ or were exposed to live M. bovis BCG bacteria at an MOI of 20. Cell supernatants were collected, and IFN- $\gamma$ or TNF- $\alpha$ was measured by ELISA (BioLegend).

For infections with $M$. tuberculosis, 8- to 12-week-old mice were infected via aerosol inhalation with $\sim 50 \mathrm{CFU}$ of $M$. tuberculosis H37Rv, and survival was monitored over time. The infectious dose was verified by CFU determination on total lung homogenates immediately following infection. For phenotyping experiments, mice were infected and sacrificed at day 30 or 60 postinfection. Animals were perfused, their lungs were isolated, and CFU counts were determined by plating on $7 \mathrm{H} 10$ agar base, followed by $\sim 3$ weeks of incubation at $37^{\circ} \mathrm{C}$. For cell quantification, a single lobe of the lung was digested in collagenase $A(150 \mathrm{U} / \mathrm{ml})$ for $1 \mathrm{~h}$ at $37^{\circ} \mathrm{C}$. Tissues were homogenized to single-cell suspensions, and the red blood cells were lysed. The cells were counted, and dead cells were excluded with $0.4 \%$ trypan blue. Histological analysis of the lung caudal lobe was performed, with formalin-fixed sections stained with H\&E or stained for acid-fast bacilli with Ziehl-Neelsen stain.

Data availability. ThPOK ChIP-seq data are available in the National Center for Biotechnology Information GEO database under the accession number GSE142069.

\section{SUPPLEMENTAL MATERIAL}

Supplemental material is available online only.

SUPPLEMENTAL FILE 1, XLSX file, $0.4 \mathrm{MB}$.

\section{ACKNOWLEDGMENTS}

This work was supported by a Foundation research grant to P.G. from the Canadian Health Research Institutes of Canada and a Foundation research grant to M.A.B. (148362) from the Canadian Health Research Institutes of Canada. P.G. holds a Distinguished James McGill Professor salary award.

We are indebted to Fiona McIntosh, Genevieve Perreault, and Susan Gauthier for outstanding technical support and to Jerry Pelletier for expert advice during this project.

\section{REFERENCES}

1. Newton C, Hien TT, White N. 2000. Cerebral malaria. J Neurol Neurosurg Psychiatry 69:433-441. https://doi.org/10.1136/jnnp.69.4.433.

2. Ghazanfari N, Mueller SN, Heath WR. 2018. Cerebral malaria in mouse and man. Front Immunol 9:2016. https://doi.org/10.3389/fimmu.2018 .02016 .

3. de Souza JB, Riley EM. 2002. Cerebral malaria: the contribution of studies in animal models to our understanding of immunopathogenesis. Microbes Infect 4:291-300. https://doi.org/10.1016/s1286-4579(02)01541-1.
4. Nitcheu J, Bonduelle O, Combadiere C, Tefit M, Seilhean D, Mazier D, Combadiere B. 2003. Perforin-dependent brain-infiltrating cytotoxic CD8 + T lymphocytes mediate experimental cerebral malaria pathogenesis. J Immunol 170:2221-2228. https://doi.org/10.4049/jimmunol.170.4 .2221 .

5. Rénia L, Potter SM, Mauduit M, Rosa DS, Kayibanda M, Deschemin J-C, Snounou G, Grüner AC. 2006. Pathogenic T cells in cerebral malaria. Int J Parasitol 36:547-554. https://doi.org/10.1016/j.ijpara.2006.02.007. 
6. Longley R, Smith C, Fortin A, Berghout J, McMorran B, Burgio G, Foote S, Gros P. 2011. Host resistance to malaria: using mouse models to explore the host response. Mamm Genome 22:32-42. https://doi.org/10.1007/ s00335-010-9302-6.

7. Hansen DS. 2012. Inflammatory responses associated with the induction of cerebral malaria: lessons from experimental murine models. PLoS Pathog 8:e1003045. https://doi.org/10.1371/journal.ppat.1003045.

8. Torre S, Langlais D, Gros P. 2018. Genetic analysis of cerebral malaria in the mouse model infected with Plasmodium berghei. Mamm Genome 29:488-506. https://doi.org/10.1007/s00335-018-9752-9.

9. Hunt NH, Golenser J, Chan-Ling T, Parekh S, Rae C, Potter S, Medana IM, Miu J, Ball HJ. 2006. Immunopathogenesis of cerebral malaria. Int J Parasitol 36:569-582. https://doi.org/10.1016/j.ijpara.2006.02.016.

10. Franke-Fayard B, Fonager J, Braks A, Khan SM, Janse CJ. 2010. Sequestration and tissue accumulation of human malaria parasites: can we learn anything from rodent models of malaria? PLoS Pathog 6:e1001032. https://doi.org/10.1371/journal.ppat.1001032.

11. de Souza JB, Hafalla JCR, Riley EM, Couper KN. 2010. Cerebral malaria: why experimental murine models are required to understand the pathogenesis of disease. Parasitology 137:755-772. https://doi.org/10.1017/ S0031182009991715.

12. Riley EM, Couper KN, Helmby H, Hafalla JCR, de Souza JB, Langhorne J, Jarra WB, Zavala F. 2010. Neuropathogenesis of human and murine malaria. Trends Parasitol 26:277-278. https://doi.org/10.1016/j.pt.2010.03.002.

13. Taniuchi I. 2018. CD4 helper and CD8 cytotoxic T cell differentiation. Annu Rev Immunol 36:579-601. https://doi.org/10.1146/annurev-immunol-042617 $-053411$.

14. Keefe R, Dave V, Allman D, Wiest D, Kappes DJ. 1999. Regulation of lineage commitment distinct from positive selection. Science 286: 1149-1153. https://doi.org/10.1126/science.286.5442.1149.

15. Brown H, Hien TT, Day N, Mai N, Chuong LV, Chau T, Loc PP, Phu NH, Bethell D, Farrar J, Gatter K, White N, Turner G. 1999. Evidence of blood-brain barrier dysfunction in human cerebral malaria. Neuropathol Appl Neurobiol 25:331-340. https://doi.org/10.1046/j.1365-2990.1999 .00188.x.

16. Villegas-Mendez A, Greig R, Shaw TN, de Souza JB, Gwyer Findlay E, Stumhofer JS, Hafalla JCR, Blount DG, Hunter CA, Riley EM, Couper KN. 2012. IFN- $\gamma$-producing CD4 $+\mathrm{T}$ cells promote experimental cerebral malaria by modulating CD8 $+\mathrm{T}$ cell accumulation within the brain. J Immunol 189:968-979. https://doi.org/10.4049/jimmunol.1200688.

17. Claser C, Malleret B, Gun SY, Wong AYW, Chang ZW, Teo P, See PCE, Howland SW, Ginhoux F, Rénia L. 2011. CD8+ T cells and IFN- $\gamma$ mediate the time-dependent accumulation of infected red blood cells in deep organs during experimental cerebral malaria. PLoS One 6:e18720. https://doi.org/10.1371/journal.pone.0018720.

18. Miyakoda M, Kimura D, Yuda M, Chinzei Y, Shibata Y, Honma K, Yui K. 2008. Malaria-specific and nonspecific activation of CD8 + T cells during blood stage of Plasmodium berghei infection. J Immunol 181: 1420-1428. https://doi.org/10.4049/jimmunol.181.2.1420.

19. Bongfen SE, Rodrigue-Gervais $\mathrm{I}-\mathrm{G}$, Berghout J, Torre $S$, Cingolani $P$, Wiltshire SA, Leiva-Torres GA, Letourneau $L$, Sladek $R$, Blanchette $M$, Lathrop M, Behr MA, Gruenheid S, Vidal SM, Saleh M, Gros P. 2012. An $\mathrm{N}$-ethyl-N-nitrosourea (ENU)-induced dominant negative mutation in the JAK3 kinase protects against cerebral malaria. PLoS One 7:e31012. https://doi.org/10.1371/journal.pone.0031012.

20. Torre S, Faucher SP, Fodil N, Bongfen SE, Berghout J, Schwartzentruber JA, Majewski J, Lathrop M, Cooper AM, Vidal SM, Gros P. 2015. THEMIS is required for pathogenesis of cerebral malaria and protection against pulmonary tuberculosis. Infect Immun 83:759-768. https://doi.org/10 .1128/IAI.02586-14.

21. Kennedy JM, Fodil N, Torre S, Bongfen SE, Olivier JF, Leung V, Langlais D, Meunier C, Berghout J, Langat P, Schwartzentruber J, Majewski J, Lathrop M, Vidal SM, Gros P. 2014. CCDC88B is a novel regulator of maturation and effector functions of T cells during pathological inflammation. J Exp Med 24:2760. https://doi.org/10.1084/jem.20140455.

22. Berghout J, Langlais D, Radovanovic I, Tam M, MacMicking JD, Stevenson MM, Gros P. 2013. Irf8-regulated genomic responses drive pathological inflammation during cerebral malaria. PLoS Pathog 9:e1003491. https:// doi.org/10.1371/journal.ppat.1003491.

23. Torre S, Polyak MJ, Langlais D, Fodil N, Kennedy JM, Radovanovic I, Berghout J, Leiva-Torres GA, Krawczyk CM, Ilangumaran S, Mossman K, Liang C, Knobeloch K-P, Healy LM, Antel J, Arbour N, Prat A, Majewski J, Lathrop M, Vidal SM, Gros P. 2017. USP15 regulates type I interferon response and is required for pathogenesis of neuroinflammation. Nat Immunol 18:54-63. https://doi.org/10.1038/ni.3581.

24. Ball EA, Sambo MR, Martins M, Trovoada MJ, Benchimol C, Costa J, Antunes Gonçalves L, Coutinho A, Penha-Gonçalves C. 2013. IFNAR1 controls progression to cerebral malaria in children and CD8 $+\mathrm{T}$ cell brain pathology in Plasmodium berghei-infected mice. J Immunol 190: 5118-5127. https://doi.org/10.4049/jimmunol.1300114.

25. Richer E, Qureshi ST, Vidal SM, Malo D. 2008. Chemical mutagenesis: a new strategy against the global threat of infectious diseases. Mamm Genome 19:309-317. https://doi.org/10.1007/s00335-008-9114-0.

26. Caignard G, Eva M, van Bruggen R, Eveleigh R, Bourque G, Malo D, Gros P, Vidal S. 2014. Mouse ENU mutagenesis to understand immunity to infection: methods, selected examples, and perspectives. Genes 5:887-925. https://doi.org/10.3390/genes5040887.

27. He X, He X, Dave VP, Zhang Y, Hua X, Nicolas E, Xu W, Roe BA, Kappes DJ. 2005. The zinc finger transcription factor Th-POK regulates CD4 versus CD8 T-cell lineage commitment. Nature 433:826-833. https://doi .org/10.1038/nature03338.

28. Segal DJ, Crotty JW, Bhakta MS, Barbas CII, Horton NC. 2006. Structure of Aart, a designed six-finger zinc finger peptide, bound to DNA. J Mol Biol 363:405-421. https://doi.org/10.1016/j.jmb.2006.08.016.

29. Sun G, Liu X, Mercado P, Jenkinson SR, Kypriotou M, Feigenbaum $L$, Galéra P, Bosselut R. 2005. The zinc finger protein cKrox directs CD4 lineage differentiation during intrathymic $T$ cell positive selection. Nat Immunol 6:373-381. https://doi.org/10.1038/ni1183.

30. Chisolm DA, Savic D, Moore AJ, Ballesteros-Tato A, León B, Crossman DK Murre C, Myers RM, Weinmann AS. 2017. CCCTC-binding factor translates interleukin 2 - and $\alpha$-ketoglutarate-sensitive metabolic changes in T cells into context-dependent gene programs. Immunity 47:251-267.e7. https://doi.org/10.1016/j.immuni.2017.07.015.

31. Vahedi G, Takahashi H, Nakayamada S, Sun H-W, Sartorelli V, Kanno Y, O'Shea JJ. 2012. STATs shape the active enhancer landscape of T cell populations. Cell 151:981-993. https://doi.org/10.1016/j.cell.2012.09.044.

32. Egawa T, Littman DR. 2008. ThPOK acts late in specification of the helper $T$ cell lineage and suppresses Runx-mediated commitment to the cytotoxic T cell lineage. Nat Immunol 9:1131-1139. https://doi.org/10.1038/ ni.1652.

33. Kojo S, Tanaka H, Endo TA, Muroi S, Liu Y, Seo W, Tenno M, Kakugawa K, Naoe Y, Nair K, Moro K, Katsuragi Y, Kanai A, Inaba T, Egawa T, Venkatesh B, Minoda A, Kominami R, Taniuchi I. 2017. Priming of lineage-specifying genes by $\mathrm{Bcl} 11 \mathrm{~b}$ is required for lineage choice in post-selection thymocytes. Nat Commun :1-13. https://doi.org/10.1038/ s41467-017-00768-1.

34. Wang L, Wildt KF, Zhu J, Zhang X, Feigenbaum L, Tessarollo L, Paul WE, Fowlkes BJ, Bosselut R. 2008. Distinct functions for the transcription factors GATA-3 and ThPOK during intrathymic differentiation of CD4+ T cells. Nat Immunol 9:1122-1130. https://doi.org/10.1038/ni.1647.

35. Kawakami K, Kinjo Y, Uezu K, Miyagi K, Kinjo T, Yara S, Koguchi Y, Miyazato A, Shibuya K, Iwakura Y, Takeda K, Akira S, Saito A. 2004. Interferon- $\gamma$ production and host protective response against Mycobacterium tuberculosis in mice lacking both IL-12p40 and IL-18. Microbes Infect 6:339-349. https://doi.org/10.1016/j.micinf.2004.01.003.

36. Langlais D, Fodil N, Gros P. 2017. Genetics of infectious and inflammatory diseases: overlapping discoveries from association and exomesequencing studies. Annu Rev Immunol 35:1-30. https://doi.org/10.1146/ annurev-immunol-051116-052442.

37. Picard C, Bobby Gaspar H, Al-Herz W, Bousfiha A, Casanova J-L, Chatila T, Crow YJ, Cunningham-Rundles C, Etzioni A, Franco JL, Holland SM, Klein C, Morio T, Ochs HD, Oksenhendler E, Puck J, Tang MLK, Tangye SG, Torgerson TR, Sullivan KE. 2018. International Union of Immunological Societies: 2017 Primary Immunodeficiency Diseases Committee report on inborn errors of immunity. J Clin Immunol 38:96-128. https://doi.org/ 10.1007/s10875-017-0464-9.

38. Bousfiha A, Jeddane L, Picard C, Ailal F, Gaspar HB, Al-Herz W, Chatila T, Crow YJ, Cunningham-Rundles C, Etzioni A, Franco JL, Holland SM, Klein C, Morio T, Ochs HD, Oksenhendler E, Puck J, Tang MLK, Tangye SG, Torgerson TR, Casanova J-L, Sullivan KE. 2017. The 2017 IUIS phenotypic classification for primary immunodeficiencies. J Clin Immunol 38: 129-143. https://doi.org/10.1007/s10875-017-0465-8.

39. Wildt KF, Sun G, Grueter B, Fischer M, Zamisch M, Ehlers M, Bosselut R. 2007. The transcription factor Zbtb7b promotes CD4 expression by antagonizing Runx-mediated activation of the CD4 silencer. J Immunol 179:4405-4414. https://doi.org/10.4049/jimmunol.179.7.4405.

40. Muroi S, Naoe Y, Miyamoto C, Akiyama K, Ikawa T, Masuda K, Kawamoto 
H, Taniuchi I. 2008. Cascading suppression of transcriptional silencers by ThPOK seals helper T cell fate. Nat Immunol 9:1113-1121. https://doi .org/10.1038/ni.1650.

41. Woolf E, Brenner O, Goldenberg D, Levanon D, Groner Y. 2007. Runx3 regulates dendritic epidermal T cell development. Dev Biol 303:703-714. https://doi.org/10.1016/j.ydbio.2006.12.005.

42. Soliai MM, Kato A, Stanhope CT, Norton JE, Naughton KA, Klinger AI, Kern RC, Tan BK, Schleimer RP, Nicolae DL, Pinto JM, Ober C. 2019. Multi-omics co-localization with genome-wide association studies reveals context-specific mechanisms of asthma risk variants. bioRxiv https://doi.org/10.1101/593558.

43. Baurecht $H$, Hotze M, Rodríguez E, Manz J, Weidinger S, Cordell HJ, Augustin T, Strauch K. 2016. Compare and contrast meta analysis (CCMA): a method for identification of pleiotropic loci in genome-wide association studies. PLoS One 11:e0154872. https://doi.org/10.1371/ journal.pone.0154872.

44. Fainaru O, Shseyov D, Hantisteanu S, Groner Y. 2005. Accelerated chemokine receptor 7-mediated dendritic cell migration in Runx3 knockout mice and the spontaneous development of asthma-like disease. Proc Natl Acad Sci U S A 102:10598-10603. https://doi.org/10.1073/pnas .0504787102 .

45. Brenner O, Levanon D, Negreanu V, Golubkov O, Fainaru O, Woolf E, Groner Y. 2004. Loss of Runx3 function in leukocytes is associated with spontaneously developed colitis and gastric mucosal hyperplasia. Proc Natl Acad Sci U S A 101:16016-16021. https://doi.org/10.1073/pnas .0407180101.

46. Cho JH, Nicolae DL, Ramos R, Fields CT, Rabenau K, Corradino S, Brant SR, Espinosa R, LeBeau M, Hanauer SB, Bodzin J, Bonen DK. 2000. Linkage and linkage disequilibrium in chromosome band 1p36 in American Chaldeans with inflammatory bowel disease. Hum Mol Genet 9:1425-1432. https://doi.org/10.1093/hmg/9.9.1425.

47. Kichaev G, Bhatia G, Loh P-R, Gazal S, Burch K, Freund MK, Schoech A, Pasaniuc B, Price AL. 2019. Leveraging polygenic functional enrichment to improve GWAS power. Am J Hum Genet 104:65-75. https://doi.org/ 10.1016/j.ajhg.2018.11.008.

48. Steinke FC, Yu S, Zhou X, He B, Yang W, Zhou B, Kawamoto H, Zhu J, Tan K, Xue H-H. 2014. TCF-1 and LEF-1 act upstream of Th-POK to promote the CD4+ T cell fate and interact with Runx3 to silence Cd4 in CD8+ T cells. Nat Immunol 15:646-656. https://doi.org/10.1038/ni.2897.

49. Alvarez JD, Yasui DH, Niida H, Joh T, Loh DY, Kohwi-Shigematsu T. 2000. The MAR-binding protein SATB1 orchestrates temporal and spatial expression of multiple genes during T-cell development. Genes Dev 14: 521-535.

50. Kakugawa K, Kojo S, Tanaka H, Seo W, Endo TA, Kitagawa Y, Muroi S, Tenno M, Yasmin N, Kohwi Y, Sakaguchi S, Kowhi-Shigematsu T, Taniuchi I. 2017. Essential roles of SATB1 in specifying T lymphocyte subsets. Cell Rep 19:1176-1188. https://doi.org/10.1016/j.celrep.2017.04.038.

51. Kitagawa Y, Ohkura N, Kidani Y, Vandenbon A, Hirota K, Kawakami R, Yasuda K, Motooka D, Nakamura S, Kondo M, Taniuchi I, KohwiShigematsu T, Sakaguchi S. 2017. Guidance of regulatory T cell development by Satb1-dependent super-enhancer establishment. Nat Immunol 18:173-183. https://doi.org/10.1038/ni.3646.

52. Sun J, Yi S, Qiu L, Fu W, Wang A, Liu F, Wang L, Wang T, Chen H, Wang L, Kadin ME, Tu P, Wang Y. 2018. SATB1 defines a subtype of cutaneous CD30+ lymphoproliferative disorders associated with a T-helper 17 cytokine profile. J Invest Dermatol 138:1795-1804. https://doi.org/10 .1016/j.jid.2018.02.028.

53. Dijkstra $A E$, Smolonska J, van den Berge $M$, Wijmenga $C$, Zanen $P$, Luinge MA, Platteel M, Lammers J-W, Dahlback M, Tosh K, Hiemstra PS, Sterk PJ, Spira A, Vestbo J, Nordestgaard BG, Benn M, Nielsen SF, Dahl M, Verschuren WM, Picavet HSJ, Smit HA, Owsijewitsch M, Kauczor HU, de Koning HJ, Nizankowska-Mogilnicka E, Mejza F, Nastalek P, van Diemen CC, Cho MH, Silverman EK, Crapo JD, Beaty TH, Lomas DA, Bakke P, Gulsvik A, Bossé Y, Obeidat M, Obeidat MA, Loth DW, Lahousse L, Rivadeneira F, Uitterlinden AG, Hofman A, Stricker BH, Brusselle GG, van Duijn CM, Brouwer U, Koppelman GH, Vonk JM, Nawijn MC, Groen HJM, Timens W, Boezen HM, Postma DS, LifeLines Cohort Study. 2014. Susceptibility to chronic mucus hypersecretion, a genome wide association study. PLoS One 9:e91621. https://doi.org/10.1371/journal.pone.0091621.

54. Li H, Durbin R. 2009. Fast and accurate short read alignment with Burrows-Wheeler transform. Bioinformatics 25:1754-1760. https://doi .org/10.1093/bioinformatics/btp324.

55. Quinlan AR, Hall IM. 2010. BEDTools: a flexible suite of utilities for comparing genomic features. Bioinformatics 26:841-842. https://doi .org/10.1093/bioinformatics/btq033.

56. Wang K, Li M, Hakonarson H. 2010. ANNOVAR: functional annotation of genetic variants from high-throughput sequencing data. Nucleic Acids Res 38:e164. https://doi.org/10.1093/nar/gkq603.

57. Langlais D, Barreiro LB, Gros P. 2016. The macrophage IRF8/IRF1 regu lome is required for protection against infections and is associated with chronic inflammation. J Exp Med 213:585-603. https://doi.org/10.1084/ jem.20151764.

58. Langmead B, Trapnell C, Pop M, Salzberg SL. 2009. Ultrafast and memory-efficient alignment of short DNA sequences to the human genome. Genome Biol 10:R25. https://doi.org/10.1186/gb-2009-10-3-r25.

59. Zhang Y, Liu T, Meyer CA, Eeckhoute J, Johnson DS, Bernstein BE Nusbaum C, Myers RM, Brown M, Li W, Liu XS. 2008. Model-based analysis of ChIP-Seq (MACS). Genome Biol 9:R137. https://doi.org/10 .1186/gb-2008-9-9-r137.

60. Heinz S, Benner C, Spann N, Bertolino E, Lin YC, Laslo P, Cheng JX, Murre C, Singh H, Glass CK. 2010. Simple combinations of lineage-determining transcription factors prime cis-regulatory elements required for macrophage and B cell identities. Mol Cell 38:576-589. https://doi.org/10 .1016/j.molcel.2010.05.004.

61. Thorvaldsdóttir H, Robinson JT, Mesirov JP. 2013. Integrative Genomics Viewer (IGV): high-performance genomics data visualization and exploration. Brief Bioinform 14:178-192. https://doi.org/10.1093/bib/bbs017.

62. Wu H, Xie MM, Liu H, Dent AL. 2016. Stat3 is important for follicular regulatory T cell differentiation. PLoS One 11:e0155040. https://doi.org/ 10.1371/journal.pone.0155040.

63. Crooks GE, Hon G, Chandonia J-M, Brenner SE. 2004. WebLogo: a sequence logo generator. Genome Res 14:1188-1190. https://doi.org/10 $.1101 /$ gr.849004.

64. McLean CY, Bristor D, Hiller M, Clarke SL, Schaar BT, Lowe CB, Wenger AM, Bejerano G. 2010. GREAT improves functional interpretation of cis-regulatory regions. Nat Biotechnol 28:495-501. https://doi.org/10 .1038/nbt.1630.

65. Gros P, Skamene E, Forget A. 1981. Genetic control of natural resistance to Mycobacterium bovis (BCG) in mice. J Immunol 127:2417-2421. 